\title{
TERAJU
}

Teraju: Jurnal Syariah dan Hukum

Volume 02 Nomor 01, Maret 2020

DOI: https://doi.org/10.35961/teraju.v2i01.62

\section{Pelaksanaan Eksekusi Hak Asuh Anak (Hadhanah) Terhadap Isteri yang Murtad dalam Perkara Nomor: 398/P.dt.G/2013/PA.Pbr di Pengadilan Agama Pekanbaru)}

\author{
Zulfan Efendi \\ STAIN Sultan Abdurrahman Kepulauan Riau \\ zulfan.efendi@stainkepri.ac.id
}

\begin{abstract}
Abstrak
Pada Putusan Perkara Nomor: 398/P.dt.G/2013/PA.Pbr, dimana Majelis Hakim Pengadilan Agama kelas IA Kota Pekanbaru memutuskan dan mengabulkan gugatan Penggugat, yakni: hak asuh anak (Hadhanah) diserahkan kepada Penggugat. Kajian ini lebih menelaah kepada proses pelaksanaan ek-sekusi hak asuh anak yang dilakukan di lapangan atas putusan tersebut. Dalam kajian dini di ketahui bahwa pelaksanaan eksekusi hingga penyelesaian akhir telah dilaksanakan sudah sesuai dengan pertimbangan dan aturan hukum yang berlaku di Indonesia. Namun ketika proses eksekusi itu di lakukan di kediaman Tergugat, keempat orang anak yang telah diputuskan Hakim hak asuhnya jatuh kepada Ayahnya (Penggugat) mengadakan perlawanan karena tidak bersedia untuk di eksekusi, dan tetap memilih untuk ikut bersama ibunya (Tergugat). Sehingga penyelesaikan akhir dalam perkara tersebut pelaksanaan eksekusi hak asuh anak ditunda sampai setelah anak tersebut mumayyiz dan di serahkan pada anak untuk memilih ayah atau ibunya sebagai pemegang hak pemeliharaannya. Dari kajian ini, perlunya kejelasan norma hukum yang menjadi acuan pelaksanaan eksekusi hak asuh anak bagi Pengadilan Agama, agar tidak menimbulkan kontradiksi yang berkelanjutan.
\end{abstract}

Kata Kunci: Hadhonah, Murtad, Pengadilan Agama 


\begin{abstract}
Abstrac
In Case Decision Number: 398 / P.dt.G / 2013 / PA.Pbr, where the Panel of Judges of the IA Religion class Pekanbaru City decided and granted the Plaintiff's claim, namely: child custody (Hadhanah) sent to the Plaintiff. This study examines the process of implementing custody of children carried out in the field on this decision. In the early study, the implementation of the final execution has been carried out in accordance with the considerations and legal rules in force in Indonesia. However, the process of compiling the execution was carried out at the Defendant's House, the class of parents who had been decided, the custody Judge fell to his father (the Plaintiff) collecting approval because he was not willing to execute, and still chose to go together (Defendant). After completing the child in this execution, the execution of the child custody is postponed until after the child mumayyiz and handed over to the child to choose the father or allow as the holder of the right to maintain. From this study, the need for clarity of legal norms that serve as a reference for the implementation of the exercise of rights for religious courts, so as not to cause contradictions that are maintained.
\end{abstract}

Keywords: Hadhonah, Apostate, Religious Court

\section{Pendahuluan}

Fenomena perebutan hak asuh (hadhanah) anak pasca perceraian orangtua adalah wujud dari pelanggaran terhadap hak-hak anak yang di atur dalam ketentuan Pasal 4, Pasal 9 Ayat (1), Pasal 11, Pasal 13, Pasal 16 Ayat (1) dan (2) UndangUndang Nomor 23 Tahun 2002 Tentang Perlindu-ngan Anak, terlebih lagi kasuskasus pere-butan anak yang berakhir pada pemaksaan, penculikan, pelarian, penyekapan, dan pe-nyiksaan anak secara fisik maupun psikis. Sehingga mengabaikan hak anak untuk memperoleh pendidikan, bermain, bergaul, dan berkreasi. Pelaku pelanggaran terhadap hak-hak anak dalam kasus perebutan anak dapat dikenakan pidana sebagaimana ditentukan dalam Pasal 80 UU No. 23 Tahun 2002 Tentang Perlindungan Anak dan Pasal 330 KUHP.

Pasal 14 Undang-Undang Nomor 23 Tahun 2002 Tentang Perlindungan Anak yang berbunyi "Setiap anak berhak untuk diasuh oleh orangtuanya sendiri, kecuali jika ada alasan atau aturan hukum yang sah me-nunjukkan bahwa pemisahan itu adalah demi kepentingan terbaik bagi anak dan merupakan pertimbangan terakhir Perceraian.
Pada umumnya menjadi penyebab ut-ama dalam sengketa pengasuhan anak di ka-renakan kasus perceraian, tidak sedikit kasus perceraian dengan cerita perseteruan yang sangat serius antara suami dan istri pasca perceraian dengan berbagai alasan yang di buat agar dapat ditetapkan sebagai peme-nang atas pemegang hak asuh anak (hadha-nah), meskipun tak sedikit pula kepentingan anak yang menjadi terabaikan.

Hak asuh anak (hadhanah) bisa saja jatuh ke tangan ayah atau ibu. Tapi yang pasti tidak mudah bagi salah satu pihak yang tidak memenangkan putusan perkara dalam hak pengasuhan anak jika keinginannya itu tidak sesuai dengan kenyataan yang ada. Persoalan hadhanah hanya berlaku ketika terjadi perceraian antara suami dan istri. Apabila suatu ikatan pernikahan itu masih berlangsung, maka tanggung jawab dan ke-wajiban atas anak menjadi tanggung jawab bersama antara ayah dan ibu. Ayah yang berperan sebagai Kepala Keluarga berkewajiban mencari nafkah dan Ibu bertugas sebagai ummu madrassah lil aulad.

Hak dan masa pengasuhan anak hukumnya wajib, karena anak yang masih me-merlukan pengasuhan ini akan 
mendapat-kan bahaya jika tidak mendapatkan penga-suhan dan perawatan, sehingga anak harus di jaga agar tidak sampai membahayakan. Selain itu ia juga harus tetap di beri nafkah dan diselamatkan dari segala hal yang dapat merusaknya. Meskipun keutamaan ibu dalam memelihara anak, tidak secara langsung ditegaskan dalam Al-qur'an, namun dapat dipahami melalui Q.S Luqman ayat 14. yang bunyinya :

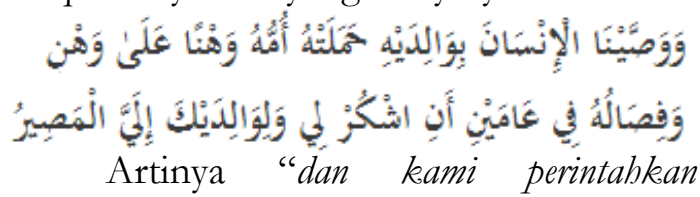
manusia untuk berbuat baik kepada kedua orangtuanya. Ibunya telah mengandungnya dalam keadaan lemah yang bertambah-tambah dan menyapibnya selama dua tahun. Bersyukurlab ${ }^{1}$ padaku dan pada orang-tuamu dan kepada Ku lab kau kembali.

Seiring dengan perkembangan panda-ngan Hukum Islam, maka ketentuan hukum yang ditetapkan dalam Undang-Undang juga memberi jalan beralihnya kuasa pengasuhan terhadap anak, diantara penyebab beralihnya kuasa pengasuhan anak dari ibu kepada ayah karena dipengaruhi oleh faktor-faktor kepentingan anak yang menghendaki hal terse-but. Berdasarkan penjelasan di atas, terjadi pada kasus dalam putusan perkara Nomor: 398/P.dt.G/2013/PA.Pbr di Pengadilan Agama Pekanbaru. Dalam posita perkara Surat Gugatan tertanggal 20 Maret 2013 yang ter-daftar di Kepaniteraan Pengadilan Pekan-baru pada Nomor 398/Pdt.G/ 2013/PA. Pbr. dimana pokok-pokok permasalahan, yakni:

Bahwa Penggugat dan Tergugat pasa-ngan yang menikah pada tanggal 18 De-sember 1992 yang telah dicatat oleh Pegawai Pencatat Nikah Kantor Urusan Agama Kecamatan Sail, Kota Pekanbaru, sesuai dengan Buku Kutipan Akta Nikah

${ }^{1}$ Bakhtiar Surat Tafsir Az-Zikra Bandung, lentera 2005.
No. 224/18/ XII/1992 tanggal 23 Desember 1992, dan sekarang telah bercerai berdasarkan Akta Cerai No. 717/AC/ 2010/PA.PBR, tanggal 03 November 2010 yang diterbitkan oleh Pengadilan Agama Pekanbaru. Selama masa perkawinan tersebut, Penggugat dan Ter-gugat telah dikaruniai 4 (empat) orang anak, yang masing-masing bernama: Cindy Nelta Putri (perempuan), 20 tahun, Bunga Shinta Bella (perempuan), umur 18 tahun, Obed Edom JJ (laki-laki), umur 9 tahun, Nico-las Gaspitaro JJ (laki-laki), umur 5 tahun. Anak-anak tersebut saat ini ikut bersama Tergugat.

Terjadinya perceraian berdasarkan Ak-ta Cerai seperti tersebut, maka sesuai dengan Komplikasi Hukum Islam Pasal 105 Huruf (a) pemeliharaan anak yang belum mumayyiz atau belum berumur 12 tahun adalah hak ibunya, huruf (b) pemeliharaan anak yang sudah mumayyiz di serahkan kepada anak untuk memilih di antara ayah atau ibunya sebagai pemegang hak pemeliharaannya sedangkan huruf (c) biaya pemeliharaan ditanggung oleh ayahnya. Menurut Penggugat penyebab rumah tangganya tidak lagi harmonis, karena Tergugat tidak jujur, suka berbohong terutama masalah biaya pemeliharaan anak-anak yang selama ini berada di bawah asuhan Tergugat, ia mintak uang de-ngan alasan untuk biaya sekolah anakanak dan biaya lainnya, tetapi sampai sekarang anak-anak tersebut tidak ada satupun yang melanjutkan sekolah.

Terutama kedua orang anak Penggugat dan Tergugat yang belum mumayyiz, atau belum berumur 12 tahun, sewaktu anak-anak tersebut berada di bawah asuhan Tergugat tahun 2010 setelah terjadi perceraian, anak ketiga yang bernama Obed Edom JJ (laki-laki), umur 9 tahun telah masuk SD kelas II dan anak ke empat yang bernama Nicolas Gaspitaro JJ (laki-laki), umur 5 tahun telah masuk TK, akan tetapi setelah keempat anak Penggugat dan Tergugat tersebut berada 
di bawah asuhan Tergugat selaku ibu kandungnya, tak satupun yang melanjutkan sekolah, sedangkan ia (Tergugat) berjanji bahwa an-ak-anak tersebut akan meneruskan pelajaran-nya di Bandung sebagai alasan untuk me-minta biaya pendidikan, akan tetapi sampai sekarang anak-anak tidak ada satupun yang melanjutkan sekolahnya.

Selanjutnya Tergugat juga telah mendidik jiwa anak-anak agar membenci Penggu-gat selaku ayah kandungnya dan keluarga Penggugat lainnya, ia meminjam HP milik anak-anak dengan mengirim SMS kepada Penggugat yang isinya sumpah serapah, caci maki terhadap Penggugat tanpa sepengetahuan mereka selaku pemilik HP, Penggugat selaku ayah kandungnya ketika mendapat SMS dari anak-anak tentu saja sangat gem-bira, akan tetapi betapa kecewanya ketika membaca isinya seperti demikian, sedangkan anakanak itu sendiri penggugat berkeyaki-nan tidak akan sampai hati mencaci maki orangtuanya sendiri sedemikian rupa, dan juga pasti anak-anak akan merasa sedih dan kecewa sekali atas sikap dan sifat ibu kandu-ngnya seperti demikian terhadap ayahnya ketika anak-anak mengetahui dan membaca SMS ibunya di maksud.

Selain penyebab di atas, Tergugat juga telah beralih agama (murtad), ia sudah bolak balik pindah agama dengan seenaknya, tanpa beban, semula Islam pindah ke Kristen, setelah itu masuk Islam Kembali, lalu pindah kembali ke agama Kristen, sedangkan kedua orang tuanya tetap beragam Islam. Tergugat masuk ke agama Kristen tersebut dengan penuh kesadarannya sendiri, berdasarkan SMS yang masuk pada HP penggugat, bahwa ia berkeyakinan Yesus Kristus adalah Tuhannya dan Penggugat sangat khawatir bahwa ia juga akan mengajak dan mempengaruhi serta memaksa anak-anak Penggugat dan Tergugat tersebut ikut ke agama yang ia anut, sedangkan Penggugat berusaha mendidik anak-anak tetap menjadi muslim yang baik;

Berdasarkan penjelasan dalam posita perkara dalam Putusan Perkara Nomor: 398/P.dt.G/2013/PA.Pbr tersebut di atas, dimana Majelis Hakim Pengadilan Agama Pekanbaru memutuskan mengabulkan guga-tan Pengugat, yaitu hak asuh anak (Hadha-nah) yang diserahkan kepada Penggugat. Jika telaah lebih lanjut, Putusan Hakim Pengadi-lan Agama Pekanbaru sebenarnya tidak me-miliki landasan yuridis, tetapi hanya di da-sarkan kepada kitab fiqh Islam, yang dimana sudah tentu seorang ibu yang murtad tidak berhak menjalankan hadhanah.

Sebenarnya jika merujuk kepada sum-bersumber hukum perkawinan Indonesia, tidak ada aturan ataupun pasal yang menya-takan hak asuh seorang ibu gugur karena pindah agama, adapun ketentuan pasal 1 ayat (11) menjelaskan pengertian kekuasaan ora-ng tua yang dalam mengasuh dan menumbuhkembangkan anak harus sesuai dengan agama yang di anutnya, sementara Pasal 42 ayat (2) UU tersebut menyatakan agama anak sebelum ia dapat menentukan pilihan-nya mengikut agama orang tuanya, tanpa ada penjelasan bagaimana jika agama kedua ora-ng tuanya berbeda. Adapun Pasal 31 ayat (4) sebenarnya mengatur mengenai kuasa asuh yang dilaksanakan oleh selain orang tua kandung, jika ternyata orang tua kandung tidak ada, atau tidak diketahui keberadaannya, atau karena suatu sebab tidak dapat melaksana-kan kewajiban dan tanggungjawabnya sehi-ngga dialihkan ke keluarga atau orang per-seorangan atau lembaga pemerintah/ masya-rakat yang disyaratkan harus seagama dengan si anak.

Merujuk pendapat Aris Bintania bahwa putusan yang diputuskan oleh Pengadilan Agama meskipun belum dilandasi oleh dasar-dasar dari pertimbangan putusan yang memadai. Apalagi dalam sistem peradilan, untuk me- 
nentukan kompetensi atau kewenangan absolut peradilan apabila terjadi sengketa kewenangan mengadili, adalah dengan meman-dang kepada aturan hukum apa suatu per-buatan hukum dilakukan. Sehingga dalam hal ini, putusan yang diambil oleh Pengadilan Agama Pekanbaru sudah tepat, meskipun Pengadilan Agama tidak berwenang menga-dili perkara selain di antara orangorang Is-lam dan meskipun si ibu pindah agama, te-tapi karena pernikahan dilakukan di Kantor Urusan Agama dan bukan di Catatan Sipil, maka tentulah Pengadilan Agama yang ber-wenang sehingga penentuan hadhanah anak juga harus tunduk kepada hukum positif yang berasal dari hukum material Islam, dan jika belum ada aturan yang mengaturnya secara detail maka hakim berwenang melakukan penggalian hukum dari khasanah fiqh Islam.

Dalam penerapan Hukum Perdata di Peradilan Agama di sana sini sering muncul kontradiksi, di satu sisi ada idealitas pene-gakan hukum dalam tatanan dan semangat kesatuan berbangsa dan bernegara yang ha-rus dikedepankan, tetapi di sisi lain juga me-nuntut penegakan norma-norma dan ideali-tas yang ditekankan oleh hukum Islam yang juga tidak dapat diabaikan, apalagi hukum acara perdata yang berlaku saat ini sebagian besarnya masih didasarkan pada aturan wa-risan penjajah Belanda. ${ }^{2}$

Khususnya dalam penelitian ini. Menurut Undang-undang Perlindungan anak, segala tindakan yang menyangkut diri anak harus selalu di tujukan untuk kepentingan terbaik bagi anak, dan aspek kepentingan terbaik bagi anak harus menjadi pertimbangan utama dalam setiap tindakan penyelenggaraan perlindungan anak.

${ }^{2}$ Aris Bintania. Hak Asuh (Hadhanah) Isteri Murtad Menurut Hukum Positif dan Hukum Islam (Analisis atas Putusan Pengadilan Agama Pangkalan Kerinci No:13/Pdt.G/2009/PA.Pkc). (Jurnal. http:// media. neliti.com), h.1-2
Begitu juga da-lam penyelenggaraan perlindungan terhadap agama anak, yang meliputi pembinaan, pem-bimbingan dan pengamalan ajaran agama, setiap anak harus dijamin untuk dapat beribadah menurut agamanya. Namun selama anak belum dapat menentukan pilihan agamanya, maka agamanya disesuaikan dengan agama orang tuanya. Selanjutnya anak dapat menentukan agama pilihannya setelah ia ber-akal dan bertanggung jawab serta memenuhi sya-rat dan tatacara sesuai ketentuan agama pilihannya dan UndangUndang.

Pada penelitian ini, Penulis tidak me-nelaah terlalu luas terkait Putusan Majelis Hakim Pengadilan Agama Pekanbaru me-mutuskan mengabulkan gugatan Pengugat, yaitu hak asuh anak (Hadhanah) yang dise-rahkan kepada Penggugat, namun dalam pe-nelitian ini lebih mengarah kepada proses pelaksanaan eksekusi hak asuh anak (hadha-nah) yang dilakukan di lapangan atas putusan tersebut, sehingga judul yang di bahas da-lam penelitian ini, yakni: "Pelaksanaan Eksekusi Hak Asuh Anak (Hadhanah) Terha-dap Isteri Yang Murtad Dalam Putusan Perkara Nomor: 398/P.dt.G/ 2013/PA.Pbr Di Pengadilan Agama Pekanbaru)."

Penelitian ini, Penulis menggunakan konsep penelitian hukum normatif. Dimana suatu penelitian hanya merupakan studi ke-pustakaan, dokumen. ${ }^{3}$ Dalam penelitian ini yang di bahas mengenai pelaksanaan ekse-kusi hak asuh anak terhadap isteri yang mur-tad di Pengadilan Agama Pekanbaru dengan berpedoman pada aturan yang berlaku.

Sumber data dalam penelitian ini, yak-ni: data yang di kumpulkan langsung diolah dan disajikan dari sumber sumber asli yang memuat informasi atau data tersebut, yakni di beberapa narasumber di

${ }^{3}$ Afifi Fauzi Abbas, Metodologi Penelitian, (Jakarta: ADE-LINA Bersaudara, 2010), Cet.I, h.155. 
Pengadilan Agama Pekanbaru. ${ }^{4}$ Berupa, Putusan Pengadilan Agama Pekanbaru, hasil diskusi dengan Ketua/Wakil Pengadilan Agama Pekanbaru, para Hakim dan para pihak yang terkait dengan pembahasan dalam penelitian ini.

Selain itu data yang mendukung data utama atau memberikan penjelasan menge-nai bahan hukum primer, yaitu data sekun-der dalam penelitian ini adalah Undang-Un-dang Nomor 1 Tahun 1974 Tentang Perkawinan, Peraturan Pemerintah Nomor 9 Ta-hun 1975 tentang pelaksanaan Undang-Un-dang Nomor 1 Tahun 1974 Tentang Perkawinan, Undang-Undang Nomor 7 Tahun 1989 Tentang Peradilan Agama jo Undang-Undang Nomor 3 Tahun 2006 jo Undang-Undang Nomor 50 Tahun 2009, Undang-Undang Nomor 23 Tahun 2002 Tentang Perlindungan Anak, Kompilasi Hukum Is-lam, dan studi kepustakaan atau dokumen-dokumen yang ada di Pengadilan Agama Pekanbaru.

\section{Pembahasan}

A. Hak Asuh Anak (Hadhanab)

Hadhanah berasal dari kata "bidnan" yang berarti lambung. Seperti kalimat "badha-na ath-thaairu baidhahu”, burung itu meng-gempit telur di bawah sayapnya, begitu juga dengan perempuan (ibu) yang mengepit an-aknya. ${ }^{5}$ Pemeliharaan anak dalam bahasa Ar-ab disebut dengan istilah "hadhanah". ${ }^{6}$ Maksudnya adalah merawat dan mendidik atau mengasuh bayi/anak kecil yang belum mam-pu menjaga dan mengatur diri sendiri. Para fuqaha mendefinisikan "al-hadbn" adalah me-

${ }^{4}$ Tatang M. Amirin, Menyusun Rencana Penelitian, (Jakar-ta: PT Raja Grafindo Persada, 1995), h. 132.

${ }^{5}$ Sayyid Sabiq, Fiqib Sunnah, jilid 2, (Jakarta: Pena Pun-di Aksara, 2007), h.237.

${ }^{6}$ Abd Rahman Ghazaly, Fiqih Munakahat, (Jakarta: Prenada Media, 2013), h.175. melihara anak kecil laki-laki atau perempuan atau orang yang kurang akal yang tidak bisa membedakan.

Al-hadhn tidak berlaku pada orang de-wasa yang sudah baligh dan berakal. Ia boleh memilih tinggal dengan siapa saja dari kedua orang tuanya yang ia sukai. Bilamana seorang laki-laki maka ia boleh tinggal sendiri karena tidak membutuhkan kedua orang tuanya. Akan tetapi syara $^{\text {ee }}$ menyuruhnya berbakti dan berbuat baik kepada mereka. Jika seora-ng perempuan, ia tidak boleh tinggal sendiri dan tidak dipaksa karena kelemahan tabi-atnya untuk menghindari kecemaran keluarganya. ${ }^{7}$ Hadhanah menurut bahasa berarti "meletakkan sesuatu dekat tulang rusuk atau di pangkuan", karena ibu waktu menyusukan anaknya meletakkan anak itu di pangkuan-nya, seakan-akan ibu disaat itu melindungi dan memelihara anaknya, sehingga "hadha-nah" dijadikan istilah yang maksudnya: pen-didikan dan pemeliharaan anak sejak dari la-hir sampai sanggup berdiri sendiri mengurus dirinya yang dilakukan oleh kerabat anak itu. ${ }^{8}$

Dalam Ensiklopedia Hukum Islam di jelaskan, hadhanah yaitu mengasuh anak ke-cil atau anak normal yang belum atau tidak dapat hidup mandiri, yakni dengan memenuhi kebutuhan hidupnya, menjaga dari hal-hal yang membahayakan, memberinya pen-didikan fisik maupun psikis, mengembang-kan kemampuan intelektual agar sanggup memikul tanggung jawab

${ }^{7}$ Ibrahim Muhammad Al-jamal, Fiqih muslimah, h.341.

${ }^{8}$ Abd. Rahman Ghazaly, Fiqih Munakahat, h.175. 
hidup. ${ }^{9}$ Hadhanah adalah tugas menjaga atau mengasuh bayi/ anak kecil yang belum mampu menjaga dan mengatur diri sendiri. Mendapat asuhan dan pendidikan adalah hak setiap anak dari kedua orangtuanya. Kedua orangtua anak itulah yang lebih utama untuk melakukan tugas ter-sebut, selama keduanya mempunyai kemam-puan untuk itu. ${ }^{10}$

Menurut Muhammad bin Ismail Salah Al-Amir Al-Khalani atau yang di sebut deng-an nama Sa ani, mengartikan hadhanah ialah pemeliharaan anak yang belum mampu ber-diri sendiri mengenai dirinya, pen-didikannya serta pemeliharaannya dari segala sesuatu ya-ng membinasakannya atau yang membahaya-kan-nya. ${ }^{11}$ Menurut Qalyubi dan Umairah: ${ }^{12}$ yang Artinya:" Hadhanah ialah menjaga anak yang tidak dapat mengurus urusannya dan mendidiknya dengan hal-hal baik". Menurut Amir Syarifuddin, Pengertian hadhanah di dalam istilah Fikih di gunakan dua kata na-mun ditunjukan untuk maksud yang sama yaitu Kafalah dan Hadhanah. ${ }^{13}$ Yang dimak-sud dengan hadhanah dan kafalah dalam arti sederhana adalah "pemeliharaan" atau "penga-suban".

Dalam arti yang lebih lengkap adalah pemeliharaan anak yang masih kecil setelah terjadinya putusnya perkawinan. Hal ini dibi-carakan

9"Hadhanah", dalam Abdul Aziz Dahlan, dkk, ed., Ensiklopedi Hukum Islam (Jakarta: Ichtiar Baru Van Hoeva, 1997), h.37.

10"Hadhanah" dalam Harun Nasution, dkk, ed., En-siklopedii Islam Indonesia (Jakarta: Djambatan, 1992), h.269.

${ }^{11}$ As-San eeani, Subulus Salam, (Surabaya: Al Ikhlas, 19-95), Cet.III, h.37.

${ }^{12}$ Syeikh Al-Syihab Al-Din Al-Qalyabi Wa Al-,Umai-rah, Al-Mahalli Juz IV, (Kairo: Dar Wahya Al-Kutub, 1971), h.88.

${ }^{13}$ Amir Syarifuddin, Hukum Perkawinan Islam di Indo-nesia, h.327. dalam fiqih karena secara praktis antara suami dan istri telah terjadi perpisahan sedangkan anak-anak memerlukan bantuan dari ayah dan/atau ibunya. Hadhanah yang dimaksud adalah kewajiban orangtua untuk memelihara dan mendidik anak mereka de-ngan sebaik-baiknya. Pemeliharaan ini men-cakup masalah pendidikan dan segala sesua-tu yang menjadi kebutuhan pokok si anak. ${ }^{14}$ Dari pengertian-pengertian hadhanah terse-but di atas dapat disimpulkan bahwa hadha-nah itu mencakup aspek-aspek:

1. Pendidikan

2. Pencukupannya kebutuhan

3. Usia (yaitu bahwa hadhanah itu di berikan kepada anak sampai usia tertentu).

Sehingga dimaksudkan dengan hadha-nah adalah membekali anak secara material maupun secara spiritual, mental meupun fi-sik agar anak mampu berdiri sendiri dalam menghadapi hidup dan kehidupannya nanti bila ia dewasa. Dalam UndangUndang No-mor 1 Tahun 1974 tidak disebutkan penger-tian pemeliharaan anak (hadhanah) secara definitif, melainkan hanya disebutkan tenta-ng kewajiban orang tua untuk memelihara anaknya. Pasal 45 ayat (1) Undang-Undang ini disebutkan bahwa, "Kedua orang tua wajib memelihara dan mendidik anak-anak mereka sebaik-baiknya”. M. Yahya Harahap dalam bukunya Pembahasan Hukum Per-kawinan Nasional, mengemukakan bahwa arti pemeliharaan anak adalah:

1. Tanggungjawab orangtua untuk mengawasi, memberi pelayanan ya-ng semestinya serta mencukupi ke-butuhan hidup dari anak oleh orang tua.

${ }^{14}$ Amir Nuruddin dan Azhari Akmal Tarigan, Hukum Perdata Islam di Indo-nesia, h.293. 
2. Tanggungjawab yang berupa pengawasan dan pelayanan serta pencukupan nafkah tersebut bersifat kontiniu (terus menerus) sampai anak itu mencapai batas umur yang legal sebagai orang dewasa yang telah bisa berdiri sendiri. ${ }^{15}$

Pengertian pemeliharaanpemeliharaan anak (hadhanah) tersebut dapat di ambil kesimpulan bahwa pemeliharaan anak adalah mencakup segala kebutuhan anak, jasmani dan rohani. Sehingga termasuk pemeli-haraan anak adalah mengembangkan jiwa intelektual anak melalui pendidikan.

Beberapa Ulama Mazhab berselisih pendapat mengenai masa asuh anak. Imam Hanafi berpendapat masa asuhan adalah 7 (tujuh) tahun untuk lelaki dan 9 (sembilan) tahun untuk perempuan. Imam Hanbali ber-pendapat masa asuh anak lelaki dan perem-puan adalah 7 (tujuh) tahun dan setelah itu diberi hak untuk memilih dengan siapa ia ak-an tinggal. Menurut Imam Syafie $i$ berpen-dapat bahwa batas mumayyiz anak adalah jika anak itu sudah berumur 7 (tujuh) tahun atau 8 (delapan) tahun. Sedangkan Imam Malik memberikan batas usia anak mumayyiz adalah 7 (tujuh) tahun. ${ }^{16}$ Kompilasi Hukum Islam Pasal 105 (a) menyebutkan bahwa batas mu-mayyiz, seorang anak adalah berumur 12 (dua belas) tahun. ${ }^{17}$ Sedangkan Undang-Undang Nomor 1 Tahun 1974 Tentang Perkawinan menyebutkan bahwa anak dikatakan mumay-yiz, jika sudah berusia

\footnotetext{
${ }^{15}$ Yahya Harahap, Hukum Perkawinan Nasional, (Me-dan: CV Zahir Trading CO, 1975), h.204.

${ }^{16}$ Syaikh Hasan Ayyub, Fikih Keluarga, (Jakarta: Pus-taka Al-Kautsar, 2006), Cet.V, h.

${ }^{17}$ Abdurrahman, Kompilasi Hukum Islam di Indonesia, (Jakarta: Akademia Pre-sindo, 2007), h.293.
}

18 (delapan belas) ta-hun atau setelah melangsungkan pernika-han. ${ }^{18}$

$$
\text { Para Ulama Fiqih }
$$

mendefinisikan: ha-dhanah yaitu melakukan pemeliharaan anak-anak yang masih kecil, baik laki-laki maupun perempuan, atau yang sudah besar tetapi be-lum mumayyiz, menyediakan sesuatu yang menjadikan kebaikannya, menjaganya dari sesuatu yang menyakiti dan merusaknya, mendidik jasmani, rohani, dan akalnya, agar mampu berdiri sendiri menghadapi hidup dan memikul tanggungjawab. Para Ulama se-pakat bahwasanya hukum hadhanah, mendi-dik dan merawat anak wajib. Tetapi mereka berbeda dalam dalam hal, apakah hadhanah ini menjadi hak orang tua (terutama ibu) atau hak anak. ${ }^{19}$

B. Dasar Hukum Hadhanah

Para ulama menetapkan bahwa pemeliharaan anak itu hukumnya wajib, sebagai-mana wajib memeliharanya selama berada dalam ikatan perkawinan. Adapun dasar hukumnya mengikuti umum perintah Allah un-tuk membiayai anak dan istri dalam firman Allah :

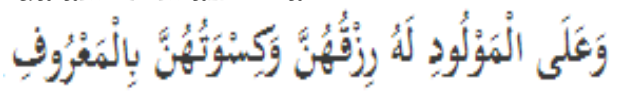

artinya: Adalab kewajiban ayah untuk memberi nafkah dan pakaian untuk anak dan istrinya. (Qs. Al-Baqarah: 233).

Kewajiban ${ }^{20}$ membiayai anak yang ma-sih kecil bukan hanya berlaku selama ayah dan ibu masih terkait dalam tali perkawinan saja, namun juga berlanjut sete-lah terjadinya perceraian.

\footnotetext{
${ }^{18}$ Lihat Undang-Undang Nomor 1 Tahun 1974 Ten-tang Perkawinan, Pasal 47.

${ }^{19}$ Amir Syarifuddin, Hukum Perkawinan Islam di Indo-nesia: Antara Figh Munakahat dan Undang-undang Perka-winan, (Jakarta: Kencana Pranada Media Group, 20-09). Cet.III, h.326.

${ }^{20}$ Amir Syarifuddin, Hukum Perkawinan Islam di Indo-nesia, h.328.
} 


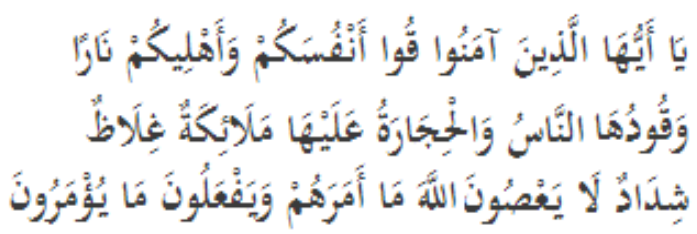

artinya: "Hai orang-orang yang beriman, peliharalah dirimu dan keluargamu dari api neraka yang bahan bakarnya adalah manusia dan batu; penjaganya MalaikatMalaikeat yang kasar, keras, dan tidak mendurbakai Allah terbadap apa yang diperintabkan-Nya kepada mereka dan selalu me-ngerjakan apa yang diperintabkan. (Qs. At-tah-rim: 6)

Pada Ayat ini orangtua diperintahkan Allah SWT untuk memelihara keluarganya dari api neraka, dengan berusaha agar selu-ruh anggota keluarganya itu melaksanakan perintah-perintah dan menjauhi larangan-la-rangan Allah, termasuk anggota keluarga da-lam ayat ini adalah anak. Kewajiban membia-yai anak yang masih kecil bukan hanya ber-laku selama ayah dan ibu masih terikat dalam tali perkawinan saja, namun juga berlanjut setelah perceraian. ${ }^{21}$ Sebagaimana sabda $\mathrm{Ra}$ sulAllah SAW: Yang Artinya: telah mencerita-kan kepada kami Mahmud bin Khalid As-Sula-mi, telah menceritakan kepada kami Al-Walid dari Abu 'Amr Al-Auza'i, telah menceritakan ke-padaku 'Amr bin Syu'aib, dari ayahnya dari kakeknya yaitu Abdullab bin 'Amr bahwa seorang wanita berkata; wahai Rasulallah, sesunggubnya anakeu ini, perutku adalah tempatnya, dan putting susuku adalah tempat minumnya, dan pangkuanku adalah rumabnya, sedangkan ayahnya telah menceraikannya dan ingin merampasnya dariku. Kemu-dian Rasulullah Saw berkata kepadanya; engkau lebih berbak

${ }^{21}$ Ibid, h.328. terbadapnya selama engkan belum menikah. (HR. Abu Daud). ${ }^{22}$

Untuk memelihara, merawat dan men-didik anak kecil diperlukan kesabaran, kebi-jaksanaan, pengertian, dan kasih sayang, se-hingga seseorang tidak dibolehkan mengeluh dalam menghadapi berbagai persoalan mereka; bahkan Rasulallah SAW sangat mengen-cam orang-orang yang merasa bosan dan ke-cewa dengan tingkah laku anak-anak me-reka. ${ }^{23} \mathrm{Hal}$ ini sebagaimana dijelaskan dalam sebuah hadis: "Ya Rasulullah, saya memiliki be-berapa orang anak perempuan dan saya mendoa-kan agar maut menemui mereka, Rasulullab SAW bersabda 'Wabai Ibnu Sa'dab (panggilan bagi Aus) jangan kamu berdo'a seperti itu, karena anak-anak itu membawa berkat, mereka akan mem-bawa berbagai nikmat, mereka akan membantu apa-bila terjadi musibah, dan mereka merupakan obat diwaktu sakit dan rezeki mereka datang dari Allah SWT.(HR. Muslim dan Abu Daud).

C. Hadhanah Menurut Hukum Positif

Pemeliharaan anak atau Hadhanah adalah kegiatan mengasuh, memelihara dan mendidik anak hingga dewasa atau mampu berdiri sendiri. ${ }^{24}$ Suami isteri memikul kewajiban untuk mengasuh dan memelihara an-ak-anak mereka, partumbuhan jasmani, ro-hani, kecerdasan dan pendidikan agamanya. $^{25}$ Seorang suami, sesuai penghasilannya, mena-nggung biaya rumah tangga, perawatan, pe-

${ }^{22} \mathrm{Abu}$ Daud Sulaiman bin Al-Asyee ats, Sunan Abu Daud Juz I, (Beirut: Daar Fikr, 2003), h. 525 .

${ }^{23} \mathrm{Abu}$ Daud Sulaiman Ibn al-Asy'ab alSijistaniy, Sunan Abi Daud, (Beirut: Daar al-Kitab al-'Arabi, tt), Juz.II, Hadis No. 1913, h.251.

${ }^{24}$ Ketentuan Umum Pasal 1 huruf $g$ Inpres No. 1/1991 tentang Kompilasi Hukum Islam

$$
{ }^{25} \text { Pasal } 77 \text { ayat (3) KHI }
$$


ngobatan dan pendidikan anak. ${ }^{26}$ Kewajiban orangtua berlaku sampai anak itu kawin atau dapat berdiri sendiri, dan kewajiban itu terus berlaku meskipun perkawinan kedua orang tua putus. ${ }^{27}$ Batas usia anak yang mampu ber-diri sendiri/dewasa adalah 21 tahun, sepan-jang anak tidak cacat fisik/mental dan belum kawin. ${ }^{28}$ Semua biaya penyusuan anak diper-tanggungjawabkan kepada ayahnya, bila su-dah meni-nggal, dibebankan kepada orang yang berkewajiban menafkahi ayah atau wali-nya. ${ }^{29} \mathrm{Jika}$ terjadi perceraian, pemeliharaan anak yang belum mumayyiz (belum 12 tahun) adalah hak ibunya, setelah mumayyiz diserahkan pada anak untuk memilih ayah atau ibunya sebagai pemegang hak pemeliha-raannya. Sedangkan biaya pemeliharaan tetap di tanggung oleh ayahnya. ${ }^{30}$ Semua biaya ha-dhanah dan nafkah anak tetap merupakan kewajiban ayah sesuai kemampuannya terha-dap anak-anaknya yang belum berusia 21 tahun. ${ }^{31}$ Anak yang belum mumayyiz berhak mendapatkan hadhanah dari ibunya, bila ibu-nya meninggal, maka kedudukannya secara berurut digantikan oleh, wanita-wanita dalam garis lurus ke atas dari ibu, ayah, wanita-wa-nita dalam garis lurus ke atas dari ayah, sau-dara perempuan anak tersebut, wanita kera-bat sedarah garis samping dari ibu dan wani-ta sedarah garis samping ayah. Bila peme-gang hadhanah ternyata tidak dapat menjamin keselamatan jasmani dan rohani anak, meskipun biaya hadhanah telah dicukupi, Pengadilan Agama dapat

${ }^{26}$ Pasal 80 ayat (4 b-c) KHI

${ }^{27}$ Pasal 45 UU. Perkawinan

${ }^{28}$ Pasal 98 ayat (1) KHI

${ }^{29}$ Pasal $104 \mathrm{KHI}$

${ }^{30}$ Pasal $105 \mathrm{KHI}$

${ }^{31}$ Pasal 149 huruf d KHI dan Pasal 156 huruf d; Pasal 41 UU. Perkawinan memindahkan hak hadhanah atas permintaan kerabat anak yang juga punya hak hadhanah. Dan bilamana ter-jadi perselisihan mengenai hadhanah dan nafkah anak maka Pengadilan Agama mem-berikan keputusan berdasarkan aturan-atu-ran di atas, bahkan Pengadilan dapat pula menetapkan nominal biaya pemeliharaan dan pendidikan anak dengan mengingat ke-mampuan ayah meskipun anak-anak itu ti-dak turut tinggal bersamanya. ${ }^{32}$ Permoho-nan soal penguasaan anak dan nafkah anak dapat diajukan bersama-sama dengan sengketa perceraian atau diajukan secara tersendiri setelah terjadinya perceraian. ${ }^{33}$ Selama proses perceraian seorang isteri dapat meminta Pengadilan menentukan halhal yang perlu untuk menjamin pemeliharaan dan Pendidi-kan anak. Karena proses perceraian tidak bisa dijadikan alasan bagi suami isteri untuk melalaikan tugas mereka terhadap an-ak-anak, harus dijaga jangan sampai harta kekayaan bersama, harta suami atau isteri menjadi terlantar atau tidak terurus dengan baik, tetapi juga pihak ketiga. ${ }^{34}$ Kewajiban dan tanggung jawab orang tua, sesuai ketentuan Pasal 26 UU. Perlindungan Anak, adalah untuk mengasuh, meme-lihara, mendidik dan melindunginya. Menumbuh kembangkan sesuai kemampuan, bakat dan minatnya dan mencegah terjadinya per-kawinan usia dini. Apabila orangtua tidak ada atau karena suatu sebab tidak dapat melaksanakan kewajiban dan tanggungjawab-nya, kewajiban itu dapat dialihkan ke keluar-ga. Namun bila orang tua justru melalaikan

\footnotetext{
${ }^{32}$ Pasal 156 huruf a, b, c, d, e, f KHI

33Pasal 66 UUPA

${ }^{34}$ Pasal 78 huruf b UUPA; Pasal 24 ayat
} (2) dan penjelasannya PP. No. 9/ 1975. 
kewajibannya, dapat dilakukan tindakan pe-ngawasan bahkan kuasa orang tua dapat di cabut melalui penetapan pengadilan. ${ }^{35}$

Permohonan penetapan pengadilan ini dapat di mintakan oleh salah satu orangtua, saudara kandung atau keluarga sampai dera-jat ketiga. Pencabutan kuasa orang tua dapat juga diajukan oleh pejabat atau lembaga yang berwenang, selanjutnya Pengadilan dapat menunjuk orang (harus seagama) atau lem-baga pemerintah/masyarakat sebagai walinya. Penetapan ${ }^{36}$ itu juga harus memuat per-nyataan bahwa perwalian tidak memutus hu-bungan darah antara anak dengan orang tua kandungnya atau menghilangkan kewajiban orang tua untuk membiayai anaknya dan adanya penyebutan batas waktu pencabutan.

Asas

penyelenggaraan perlindungan anak adalah asas kepentingan terbaik bagi anak, artinya dalam semua tindakan me-nyangkut dirinya maka kepentingan terbaik baginya harus menjadi pertimbangan uta-ma. ${ }^{37}$ Mengenai penyelenggaraan perlindung-an terhadap agama anak, Negara, pemerin-tah, masyarakat, keluarga, orangtua, wali dan lembaga sosial harus menjamin setiap anak untuk beribadah menurut agamanya dan se-belum anak dapat menentukan pilihannya, di sesuaikan dengan agama orang tuanya. Per-lindungan meliputi pembinaan, pembimbi-ngan dan pengamalan ajaran agama. ${ }^{38} \mathrm{Anak}$ dapat menentukan agama pilihannya setelah ia berakal dan bertanggung jawab serta me-menuhi syarat dan tatacara sesuai ketentuan agama pilihannya dan Ketentuan UndangUndang. ${ }^{39}$

D. Syarat-Syarat Menjalankan Hadhanah

Seorang hadhanah atau hadbin yang menangani dan menyelenggarakan kepenti-ngan anak kecil yang diasuhnya, yaitu adanya kecukupan dan kecakapan yang memerlukan syarat-syarat tertentu. Jika syarat-syarat itu tidak terpenuhi satu saja maka gugurlah ke-bolehan menyelenggarakan hadhanah. Adapun syarat-syaratnya antara lain:

1. Baligh

2. Berakal: Orang lemah akal tidak akan dapat menyempurnakan hak hadha-nah. ${ }^{40}$ Malikiyah

mensyaratkan cerdas, tiada hadhanah bagi orang du-ngu lagi mubazir, Hanabilah mensyaratkan ti-dak berpenyakit sopak atau kusta yang harus di asingkan. ${ }^{41}$

3. Mampu merawat: dapat memelihara akhlak dan kesehatan badan si anak. Orang yang uzur, sakit atau sibuk tidak berhak hadhanah. Adapun karyawati perusahaan atau pekerja yang pekerja-annya menghambat perawatan anak tidak berhak hadhanah, tetapi bila ia masih dapat menjaga dan mengurusi anak maka tidak gugur haknya. Peker-ja di Mesir seperti dokter, karyawati dan semisalnya tidak di gugurkan hak hadhanahnya karena ada juga yang mampu mengurusi anak, ada yang de-ngan pertolongan kerabat atau orang yang menggantikannya mengurusi an-ak. Orang buta juga dianggap lemah memegang

\footnotetext{
${ }^{39}$ Penjelasan Pasal 42 ayat (2) UU. Perlindungan Anak

${ }^{40}$ Muhyiddin al-Nawawi, al-Majmĩu'..., j-18, h. 320 .

${ }^{41}$ Ibid.., j-7, h. 726.
} 
hadhanah karena tidak ma-mpu mewujudkan tujuan hadhanah. ${ }^{42}$

4. Akhlak terpercaya: tiada hadhanah ba-gi orang yang tidak bisa dipercaya me-rawat dan membina akhlak anak, se-perti orang fasik, pemabuk, pezina at-au perbuatan haram lainnya. Tetapi menurut Ibnu Abidin ibu kandung ya-ng fasik dan dapat merusak anak tetap berhak selama umur anak belum da-pat memikirkan dan memahami sifat tercela ibunya tetapi jika ia sudah bera-kal hak ibu dicabut. Malikiyah men-syaratkan tempat tinggal yang aman, tiada hadhanah orang yang rumah at-au lingkungan sekitarnya penuh kefasi-kan karena di khawatirkan merusak anak atau hartanya dicuri dan diram-pas. ${ }^{43}$ Menurut Muhyiddin al-Na-wawi, orang fasiq tidak akan dapat menunaikan hak hadhanah dan akan mengam-bat perkembangannya sehingga anak tidak akan bahagia bersamanya, sehi-ngga tidak boleh di berikan kepada-nya. ${ }^{44}$

5. Islam (dibahas tersendiri)

6. Merdeka: Tiada hadhanah bagi orang yang tidak merdeka. ${ }^{45}$ Hadhanah ${ }^{46}$ tidak boleh diberikan kepada seorang sahaya karena ia tidak akan sanggup melaksa-nakan sambil mengabdi kepada tuan-nya.

\footnotetext{
42Wahbah, al-Fiqh al-Islầmi..., j-7, h. 726.

${ }^{43}$ Ibid., h. 727.

${ }^{44}$ Muhyiddin al-Nawawi, al-Majmũu'..., j-18, h. 320 .

${ }^{45}$ Zakariya al-Anshary, Fath al-Wah..., j-2,

h. 214.

h. 214 .
}

E. Syarat Khusus bagi Kalangan Perempuan

1. Tidak menikah dengan orang lain, di dasarkan pada hadis Nabi:

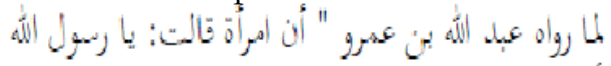

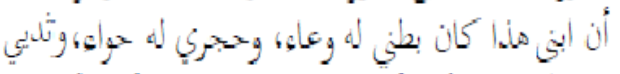

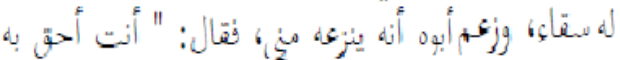

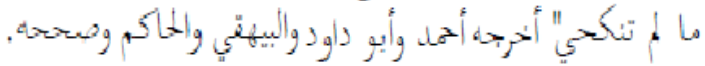

artinya: Riwayat Abdullah ibn Umar, ba-bwa seorang perempuan berkata, wahai Rasulallah, anakku ini perutku yang me-ngandungnya, dua susuku yang menyapih-nya, lambungku menaunginya, dan bapak-nya ingin merebutnya dariku, Rasulullah bersabda: engkau berbak dengannya selagi belum menikah. ${ }^{47}$

Tetapi menurut Imam Malik, Abu Ha-nifah dan Hasan al-Bashry, wanita ya-ng menikah tidak menggugurkan hak-nya karena firman Allah:

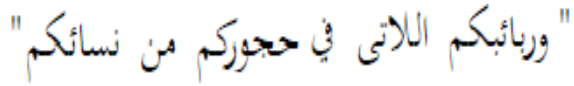

Juga karena Nabi menikah dengan Ummu Salamah yang punya anak ber-nama Zainab yang tetap tinggal deng-an ibunya. Menurut Muhyiddin al-Nawawi Hadis Nabi memang tidak membolehkan wanita yang terikat per-kawinan, riwayat ini karena memang bapak si anak tiada kalaupun ada ia rela. Ia menjelaskan Ibnu Abbas ada meriwayatkan bahwa Ali ibn Abi Ta-lib, Ja'far ibn Abi Talib dan Zaid ibn Haritsah memperebutkan hadhanah atas putri Hamzah ibn Abd al-Mutalib di depan Nabi: Ja'far berkata; aku le-bih berhak karena aku anak pamannya bibinya pun isteriku, Ali berkata; aku lebih

${ }^{47}$ Lihat al-Sayyid al-Sabiq, al-Fiqh...,j-2, h. 344.; Muh-yiddin al-Nawawi, al-Majmũu'..., j-18, h. 321. 
berhak karena selain aku anak pamannya puteri Nabi yang merupa-kan putri dari putra pamannya pun is-teriku, Zaid berkata; aku lebih berhak karena dia putri saudaraku dan Nabi juga saudara Zaid, Maka Nabi memutuskan untuk bibi (khâlah) si anak (yai-tu isteri Ja'far). Menurut Muhyiddin al-Nawawi, Hadis Nabi memang tidak membolehkan wanita yang terikat per-kawinan, tetapi dalam kasus ini tidak ada seorang pun perempuan yang tidak terikat dalam perkawinan. ${ }^{48}$

Menurut al-Syaukani, para fuqaba ba-nyak yang musykil mengenai putusan Nabi pada Ja'far karena ia bukan mah-ram si anak, kekerabatannya sama de-ngan Ali, jika untuk bibinya ia bersua-mi yang itu menggugurkan haknya, menurut al-Syaukani putusan Nabi itu untuk bibinya (isteri Ja'far), perkawin-an tidak menggugurkan hak hadhanah ketika suami ridha. Begitu juga penda-pat Ahmad, alHasan al-Bashri dan Imam Yahya ibn Hazm. Menurut se-bagian pendapat menikah itu hanya menggugurkan hak ibu (kandung) ka-rena bapak si anak pasti enggan, dan tidak mengugurkan hak ibu pengasuh yang lain, hak ibu juga tidak gugur bila yang enggan bukan si bapak. ${ }^{49}$

2. Si wanita ada pertalian darah dengan anak, seperti ibunya, saudarinya, ne-neknya. Tiada hadhanah bagi para put-ri paman dan bibi dari bapak, paman dan bibinya ibu karena bukan mahram, tetapi menurut Hanafiyah mereka berhak hadhanah jika si anak perem-puan (juga).

h. 325 .

${ }^{48}$ Muhyiddin al-Nawawi, al-Majmũu', j-18,

${ }^{49}$ Ibid.. h. 327.
3. Ia tidak menolak hadhanah meskipun tidak di upah sementara bapaknya ti-dak mampu mengupah, menurut Ha-nafiyah bila ada kerabat wanita mau melakukan hadhanah secara cumacu-ma gugur hak yang mengharap upah.

4. Rumah tempat hadhanah bukan ru-mah yang tidak disenangi/tidak di su-kai anak meskipun kerabatnya, karena akan menyiksa \& merusak dirinya.

F. Syarat Khusus bagi Kalangan LakiLaki

1. Mahram si anak, Hanafiyah dan Hana-bilah membatasi sampai umur 7 tahun khawatir khalwat keduanya. Tiada ha-dhanah bagi putra paman dari bapak terhadap anak perempuan, Hanafiyah membolehkan jika tidak ada 'Ashâbah selain putra paman, diserahkan pada-nya dengan perintah Hakim jika ia da-pat dipercaya dan tidak dikhawatirkan timbul fitnah. Begitu juga pendapat Hanabilah jika memang yang lain ber-uzur. Syafi'iyah membolehkan jika ada diawasi oleh anak perempuannya atau yang lain seperti saudarinya yang dapat dipercaya, jika ia lagi tidak bersama dalam perjalanannya maupun muqim diserahkan kepada saudarinya bukan kepada si lelaki.

2. Pemegang hadhanah, bapak atau yang lainnya memiliki wanita yang baik da-lam melakukan hadhanah, seperti is-teri, ibu, atau bibinya karena laki-laki tidak memiliki kemampuan dan kesa-baran dalam mengurusi anak, berbeda dengan wanita. Menurut Malikiyah jika tidak ada ia tidak berhak hadhanah. Menurut Zakariya alAnshary, orang bencong (khunśa) laki-laki tidak didulu-kan atas laki- 
laki meskipun ia mengaku dengan sumpah bahwa ia perempu-an. ${ }^{50}$

G. Hadhanab Menurut Fikih

Ketika pengasuhan anak merupakan hak dasar ibu, maka para ulama menyimpul-kan, kerabat ibu lebih didahulukan daripada kerabat ayah. ${ }^{51}$ Karenanya, urutan orang-orang yang berhak mengasuh anak, sebagai be-rikut: Ibu, tetapi jika ada faktor yang mem-buatnya tidak layak di dahulukan, maka hak pengasuhan dialih-kan kepada ibunya (ne-nek) dan seterusnya.

Lalu, jika ada faktor yang menghalangi mereka didahulukan maka dialihkan kepada ibu ayah (nenek). Berikutnya adalah saudara perempuan kandung, saudara perempuan dari ibu, saudara perempuan dari ayah, putri saudara perempuan kandung, putri saudara perempuan dari ibu, bibi kandung dari ibu (al-khalah asy-syaqiqah), bibi dari ibu (al-khalah liumm), bibi dari ayah (al-khalah liab), putri saudara perempuan dari ayah, putri saudara laki-laki kandung, putri saudara lakilaki dari ibu, putri saudara laki-laki dari ayah, bibi kandung dari ayah (al„ammah asy-syaqiqah), bibi dari ibu (al„ammah liumm), bibi dari ayah (al„ammah liab), saudara perempuan nenek dari ibu (khalah al-umm), saudara perempuan nenek dari ayah (khalab liab), saudara pe-rempuan kakek dari ibu (,ammah al-umm), saudara perempuan kakek dari ayah (,,ammah li-ab), dengan mengutamakan yang memiliki hubungan kandung di antara mereka. ${ }^{52} \mathrm{Jika}$ anak kecil

h. 214 .

${ }^{50}$ Zakariya al-Anshary, Fath al-Wab..., j-2,

${ }^{51}$ Wahbah Al-Zuhaili, Al-Fiqh Al-Islami wa Adillatuh Juz VII, (Damaskus: Daar Al-Fikr, 1984), h.680.

${ }^{52}$ Sayyid Sabiq, Fiqih Sunnah Sayyid Sabiq Jilid 2, (Jakar-ta: Al-I'tishom, 2008), h. 529-530. tersebut tidak punya kerabat wa-nita di antara orang-orang di atas, atau seka-lipun ada tapi tidak layak mengasuh, maka hak asuh di alihkan kepada kerabat laki-lakinya berdasarkan urutan hak menerima waris.

Dengan demikian, hak asuh beralih kepada ayah, kakek dari ayah, dan sete-rusnya. Berikutnya adalah saudara laki-laki kandung, saudara laki-laki dari ayah, putra saudara lakilaki kandung, putra saudara laki-laki dari ayah, putra saudara laki-laki kandung, putra saudara laki-laki dari ayah, pa-man kandung dari ayah, paman dari ayah, saudara laki-laki kandung kakek dari ayah (,amm abibi asy-syaqiq), dan saudara laki-laki kakek dari ayah (,amma abibi li"ab). ${ }^{53} \mathrm{Jika}$ tidak terdapat kerabat laki-laki ashabah, atau sekalipun ada tapi tidak layak mengasuh, maka hak asuh dialihkan kepada mahram kerabat laki-lakinya yang bukan ashabah. Dengan demikian, hak asuh diberikan secara urut kepada kakek dari ibu, saudara laki-laki dari ibu, putra saudara laki-laki dari ibu, saudara lakilaki kakek dari ibu, sau-dara laki-laki kandung ibu, saudara laki-laki nenek dari ayah (al-khal liab), dan saudara laki-laki nenek dari ibu (al-khal liumm) ${ }^{54}$

Jika anak kecil tersebut tidak punya kerabat sama sekali, maka hakim menunjuk pengasuh wanita yang akan mendidiknya. Karena pengasuhan anak kecil merupakan suatu keharusan, dan orang yang paling pan-tas yang mengasuhnya adalah kerabatnya sendiri. Sementara ada kerabat yang hubu-ngannya lebih dekat daripada yang lain. Ka-renanya, Wali-Wali anak tersebut didahu-lukan karena merekalah yang memiliki we-

${ }^{53}$ Ibid., h. 530.

${ }^{54}$ Ibid., h. 530. 
wenang dasar untuk memenuhi kemasla-hatannya.

Tapi jika mereka tidak ada, atau sekali-pun ada tapi tidak layak mengasuh, maka hak asuh dialihkan kepada kerabat yang lebih dekat dan seterusnya. Jika tidak punya kera-bat sama sekali, maka hakim bertanggung jawab menunjuk orang yang layak menga-suhnya. ${ }^{55}$ Sebagaimana hak mengasuh anak pertama diberikan kepada ibu, maka para ahli fikih menyimpulkan bahwa keluarga ibu dari seorang anak lebih berhak daripada ke-luarga bapaknya. Menurut kalangan mazhab Hanbali berpendapat bahwa hak asuh anak dimulai dari ibu kandung, nenek dari ibu, kakek dari ibu, bibi dari kedua orang tua, saudara perempuan seibu, saudara perem-puan seayah, bibi dari kedua orang tua, bi-binya ibu, bibinya ayah, bibinya ibu dari jalur ibu, bibinya ayah dari jalur ibu, bibinya ayah dari pihak ayah, anak perempuan dari sau-dara laki-laki, anak perempuan dari paman ayah dari pihak ayah kemudian kerabat terdekat. ${ }^{56}$ Menurut kalangan mazhab Hanafi hak asuh berturut-turut dialihkan dari ibu kepada:

1. Ibunya ibu.

2. Ibunya ayah.

3. Saudara-saudara perempuan kandu-ng.

4. Saudara-saudara perempuan seibu.

5. Saudara-saudara perempuan seayah.

6. Anak perempuan dari saudara perempuan kandung.

7. Anak perempuan dari saudara se ibu.

${ }^{55}$ Ibid., h. 530

${ }^{56}$ Wahbah Al-Zuhaili, Al-Figh Al-Islami wa Adillatub Juг VII, (Damaskus: Daar Al-Fikr, 1984), h.683.
8. Demikian seterusnya hingga pada bibi dari pihak ibu dan ayah. ${ }^{57}$

Sedangkan menurut kalangan mazhab Maliki, hak asuh berturutturut dialihkan dari ibu kepada:

1. Ibunya ibu dan seterusnya ke atas.

2. Saudara perempuan ibu sekandung.

3. Saudara perempuan ibu seibu.

4. Saudara perempuan nenek perempuan dari pihak ibu.

5. Saudara perempuan kakek dari pihak ibu.

6. Saudara perempuan kakek dari pihak ayah.

7. Ibu ibunya ayah.

8. Ibu bapaknya ayah dan seterusnya. ${ }^{58}$

Menurut mazhab Syafie $i$, hak atas asuhan secara berturut-turut adalah:

1. Ibu.

2. Ibunya ibu dan seterusnya hingga ke atas dengan syarat itu mereka adalah pewaris-pewaris si anak.

3. Ibu dari ibunya ayah dan seterusnya hingga ke atas dengan syarat mereka adalah pewarispewarisnya pula.

4. Saudara-saudara perempuan kandung.

5. Saudara-saudara perempuan seibu.

6. Saudara-saudara perempuan seayah.

7. Anak perempuan dari saudara perempuan kandung.

8. Anak perempuan dari saudara se ibu.

9. Demikian seterusnya hingga pada bibi dari pihak ibu dan ayah. ${ }^{59}$

${ }^{57}$ Peunoh Daly, Hukum Perkawinan Islam: Suatu Studi Dalam Kalangan Ablussunnah dan Negaranegara Islam, (Jakarta: Bulan Bintang, 2005), h. 87.

${ }^{58}$ Peunoh Daly, Hukum Perkawinan Islam: Suatu Studi Dalam Kalangan Ablus-sunnab dan Negaranegara Islam, (Jakarta: Bulan Bintang, 2005), h. 87.

${ }^{59}$ Wahbah Al-Zuhaili, Al-Figh Al-Islami wa Adillatuh Juz VII, (Damaskus: Da-ar Al-Fikr, 1984), h.683. 
Berdasarkan penjelasan tersebut, dapat diambil kesimpulan bahwa mayoritas ulama sepakat bahwa kalangan perempuan lebih berhak menjalankannya ketimbang kalangan laki-laki, karena mereka lebih dalam hal belas kasih, ketelatenan merawat, kesabaran dan lebih intens menjaganya, hanya saja masing-masing berbeda-beda menentukan urutan-urutan siapa yang lebih utama. Menurut Wa-hbah alZuhaili, secara garis besar pendapat masing-masing mazhab urutannya adalah sebagai berikut:

1. Hanafiyah: ibu kandung, ibu dari ibu (nenek), ibu dari bapak (nenek), saudari-saudari si anak, bibi dari ibu, putri-putri dari saudari si anak, putri-putri dari saudara si anak, bibi dari bapak dst'Ashâbah sesuai sys-tem kewarisan.

2. Malikiyah: ibu kandung, nenek dari ibu, bibi dari ibu, nenek dari bapak, saudari si anak, bibi dari bapak, putri dari saudara si anak, kemudi-an penerima wasiat yang lebih uta-ma dari 'Ăshâbah.

3. Syafi'iyah: ibu kandung, nenek dari ibu, nenek dari bapak, saudari-saudari si anak, bibi, putri-putri saudara si anak, putri-putri saudari si anak, bibi dari bapak, semua mahram waris sesuai tertib waris.

4. Hanabilah: ibu kandung, nenek dari ibu terus ke atas, nenek dari bapak terus ke atas, kemudian saudari kandung, saudari seibu, saudari se-bapak, kemudian bibi dari ibu se-kandung, bibi dari ibu seibu, bibi dari ibu sebapak, kemudian bibi da-ri bapak, kemudian bibi ibu (sau-dari nenek), kemudian bibi bapak (saudari nenek) sampai ke atas, kemudian putri saudara si anak, kemudian putri pamannya bapak se- lanjutnya tersisa 'Ashâbah mulai dari yang terdekat. ${ }^{60}$

Jika si anak tidak punya kerabat di an-tara muh-rimmuhrimnya di atas, atau punya tetapi tidak pandai mengasuh, maka pindahlah tugas tersebut ke para 'as-hẫbah laki-laki, yaitu: bapak, kakek terus ke atas, saudara dan putra-putranya terus ke bawah, paman-pam-an dan putraputranya. Tetapi tidak dapat diterima yang bukan mahram, seperti putra paman atas anak perempuan untuk menjaga dari fitnah.

Apabila tidak punya kerabat sama se-kali Menurut Hanafiyah, hadhanah pindah ke ₹̛̂ al-arbâm, yaitu saudara ibu, putranya, paman ibu, paman dari bapak se-kandung kemudian seibu, karena mereka berhak men-jadi wali nikah sehingga juga berhak menja-lankan hadhanah. Begitu juga menurut Ha-nabilah, baik anak laki-laki atau perempuan. Selanjutnya Hakim menyerahkan si anak ke orang kepercayaan pilihan si anak. Un-dang-undang Suriah tidak mengambil ketentuan ini dan mencukupkan pada 'Ashâbah tidak ke zu al-ar-bâm. ${ }^{61}$ Menurut Wahbah alZuhaili, tidak berhak hadhanah orang yang bukan ahli waris si anak dari $2 \hat{u}$ alarbâm yaitu putra dari anak perempuan, putra saudari, putra saudara ibu dan bapaknya ibu, paman dari bapak dan dari ibu, karena hak hadhanah hanya untuk orang yang kekerabatannya kuat yang tidak ada pada ₹û al-arbâm laki-laki. ${ }^{62}$

Menurut Sayyid al-Sabiq, jika tidak pu-nya kerabat sama sekali, maka pengadilan memutuskan siapa orang yang patut melaku-kan dan
${ }^{60}$ Ibid..
${ }^{61}$ Wahbah, al-Fiqh al-Islami..., j-7, h. 723-4.
${ }^{62}$ Ibid.. 
melaksanakan pengasuhan dan pendidikannya. ${ }^{63}$

H. Tinjauan Hak Hadhanah Isteri NonMuslim

Syafi'iyah dan Hanabilah mensyarat-kan wanita pelaksana hadhanah harus Islam, tiada hak dan kewe-nangan wanita kafir atas anak muslim karena akan mempengaruhi agama si anak. Sedangkan menurut Zakariya al-Anshary, hadhanah ibu yang kafir diterima karena hak hadhanah itu memang miliknya. ${ }^{64}$ Menurut Abu Sa'id al-Istakhri, boleh dise-rahkan ke orang kafir berdasarkan riwayat Abdul Hamid ibn Salamah:

$$
\begin{aligned}
& \text { لما روى عبد الحميد ابن سلمة عن أبيه أنه قال: أسلم أبي وأبت أمي } \\
& \text { أن تسلم وأنا غلاج، فاختصما إلى الني صلى الله عليه وسلم فقال: }
\end{aligned}
$$

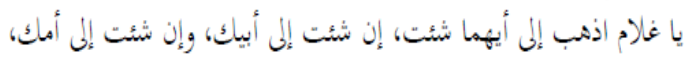

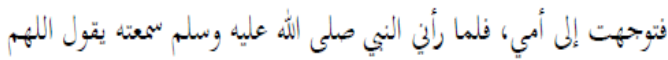

$$
\begin{aligned}
& \text { الدهاه فلمت إلى أني فقعدت في حجره }
\end{aligned}
$$

Artinya: "Riwayat dari Abdul Hamid ibn Salamah dari bapaknya, bahwa ia berkata: Ba-pakku masuk Islam tetapi ibuku enggan, aku masih anak kecil, keduanya memperebutkanku pada Nabi, Nabi berkata: hai anak pergilah ke-pada sia-pa kau kehendaki dari keduanya, jika kau mau kepada bapakmu dan jïka kau mau ke-pada ibumu, maka aku menuju ibuku, melibat-ku begitu ku dengar ia berkata, ya Allah...tunjuki-lah dia, aku lantas berbalik ke bapakku dan duduk di pangkunya."

Menurut al-Istakhri, ibu kafir zimmi lebih berhak atas anak daripada bapaknya yang muslim sampai anak berusia 7 tahun, setelah itu bapak berhak, begitu juga anak kafir zimmi dalam hadhanah sama seperti anak muslim, ibu lebih berhak atasnya. Te-tapi jika si anak

${ }^{63}$ al-Sayyid al-Sabiq, al-Fiqh..., j-2, h. 341.

${ }^{64}$ Zakariya al-Anshary, Fath al-Wah..., j-2, h. 214 . menyifatkan dirinya sebagai muslim maka ia direbut dari orang kafir zimmi benar atau pun tidak Islamnya. ${ }^{65}$ Menurut Muhyiddin al-Nawawi, hadhanah tidak boleh diserahkan ke orang kafir karena tidak akan wujud kesejahteraan anak, ia akan merusak agamanya dan itu mudharat yang paling besar. Menurutnya hadis tersebut, yang telah dijadikan dasar oleh Abu Hanifah, Ibnu Qasim alMaliky dan Abu Tsaur telah dimansukh, karena jumhur telah berijma' bah-wa anak muslim tidak boleh diserahkankan ke orang kafir. Hadist ini dari segi sanad memang dapat jadi hujjah, tetapi tempat patokan hujjah ada dua yaitu ibu yang kafir dan hak (anak) memilih. ${ }^{66}$ Yang berhujjah nasakh menggunakan dalildalil yang umum, misalnya firman Allah, Surat al-Nisa, ayat 141:

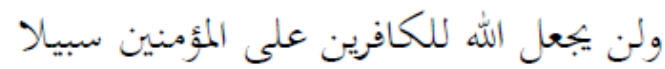

Artinya: "Dan Allab tidak akan mem-berikan jalan kepada orang-orang kafir menguasai orang-orang mukmin". Ibnu Qayyim berhujjah dengan firman Allah:

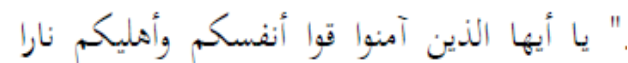

Sehingga melindungi anak lebih didu-lukan dari-pada haknya memilih atau pun mencabut undi, karena untuk kebaikannya. Diceritakan dari gurunya Ibnu Taimiyah: bahwa dua orang tua memperebutkan anak di depan hakim, hakim menyuruh anak memilih sehingga si anak memilih bapaknya, sang ibu bertanya apa sebab anak lebih me-milih bapaknya, maka hakim bertanya kepa-da si anak yang menjawab; ibuku mengi-rimku se-tiap hari ke juru tulis dan ahli figh

${ }^{65}$ Al-Nawawi, Raudhat ..., j-6, h. 504.

${ }^{66}$ Muhyiddin al-Nawawi, al-Majmĩu'..., j-18, h. 321 
yang keduanya suka memukulku, sementara bapakku membiarkanku bermain bersama teman-temanku. Lantas hakim memutus ha-dhanah untuk ibunya. Menurut Ibnu Taimiyah se-mangat syarak berkehendak menjaga kemaslahatan anak sehingga putusan hukum pun adalah untuk kemaslahatan dunia dan akhirat. Menurut al-'Imrany tujuan kebahagiaan anak tidak akan wujud pada orang ka-fir, tidak dapat dipercaya dia tidak akan me-mpengaruhi dan merusak agamanya, ia ber-pandangan hadis ini tidak begitu dikenal dikalangan penukil hadis, jikapun benar ma-ka mestilah Nabi sudah tahu si anak bakal memilih bapaknya makanya Nabi menyu-ruhnya memilih, jadi hadis ini khusus untuk si anak tidak dalam kasus yang lain. ${ }^{67}$

Menurut al-Sayyid al-Sẫbiq, wanita non-muslim tidak berhak hadhanah, tetapi golongan Hanafi, Ibnu Qasim, bahkan Ma-liki serta Abu Tsaur, berpendapat hadhanah tetap dapat dilakukan oleh pengasuh yang kafir, sekalipun si anak muslim, karena ha-dhanah itu tidak lebih dari menyusui dan melayaninya, kedua hal ini boleh dilakukan oleh wanita kafir.

Meskipun begitu golongan Hanafi mensyaratkan kafirnya bukan karena murtad, sebab orang kafir karena murtad dapat dipenjara sampai ia taubat dan kembali dalam Islam atau mati dalam penjara, sehingga ia tidak boleh diberi kesem-patan mengasuh anak kecil, kecuali bila ia sudah taubat dan kembali ke Islam. ${ }^{68} \mathrm{Abu}$ Dawud dan Nasa'i meriwayatkan: "Babwa Rafi' ibn Sinan masuk. Islam tetapi isterinya enggan, lalu ia (isterinya) datang ke Nabi dan berkata: ini putriku, ia sedang disusui dan hampir disapib, lalu Rafi' menyabut: ini putriku,

${ }^{67} \mathrm{Ibid}$., h. 324-5.

${ }^{68}$ al-Sayyid al-Sabiq, al-Fiqh..., j-2, h. 343-4. maka Nabi bersabda: ya Allab berilab anak ini bidayah, lalu anak putri itu condong ke bapaknya, lalu diambil lab oleh bapaknya."

Hanafiyah dan Malikiyah tidak men-syaratkan Islam, pemegang hadhanah boleh abl al-kitâb atau agama lain baik ibunya atau yang lain. Karena berdasarkan riwayat $\mathrm{Abu}$ Dawud dan periwayat lain bahwa Nabi SAW menyerahkan pada pilihan anak untuk me-milih antara bapaknya yang muslim dan ibu-nya yang kafir, si anak cendrung memilih ibunya sehingga Nabi berdo'a: Ya Allah tunjukilah dia, dalam hadhanah tidak akan berbeda dengan perbedaan agama. Tetapi Hanafiyah dan Malikiyah berbeda pendapat mengenai masa berakhirnya hadhanah wani-ta non-muslim, menurut Hanafiyah sampai si anak berakal dalam agama di umur baligh-nya yaitu 7 tahun atau bila nampak indikasi membahayakan agamanya seperti si wanita non-muslim mulai mengajarkan agamanya atau mengajak anak ke rumah ibadahnya at-au kembali minum khamr, memakan daging babi dan ini lah yang di pegang dalam pe-radilan Mesir. Sementara menurut Malikiyah hak hadhanah wanita non-muslim terus berlangsung hingga berakhirnya masa hadhanah menurut syarak, tetapi ia dilarang memberi anaknya minum khamr dan makan babi, jika kita khawatir ia akan melakukan itu maka ditunjuk seorang muslim yang diberi hak mengawasi si anak dari kerusakan.

Diperselisihkan juga pemegang hadha-nah laki-laki nonmuslim, menurut Hanafi-yah pemegang hadhanah laki-laki harus Is-lam dan seagama, berbeda dengan wanita, karena hadhanah termasuk persoalan pengu-asaan atas diri, tiada 
kewenangan jika berbe-da agama, hak hadhanah didasarkan sistem kewarisan dan laki-laki non-muslim tidak ada hubungan waris. Walaupun misalnya si anak Kristen atau Yahudi memiliki dua saudara yang satu muslim yang satu kafir maka hak hadhanah bagi yang non-muslim. Sementara menurut Malikiyah pemegang hadhanah laki-laki tidak harus muslim, sama seperti wanita, karena hak hadha-nah tidak akan diberikan kepada mereka selagi masih ada kalangan perempuan yang lebih baik melaksanakan hadhanah apalagi hadhanah adalah hak kalangan perempuan. $^{69}$

I. Murtad

Murtad berasal dari bahasa Arab Rad-da yang artinya kembali, menolak, mema-lingkan. Pengertian murtad menurut Wah-bah Zuhaili kembali pada jalan di-mana dia datang. Atau lebih sepesifik lagi, pindah dari agama Islam ke agama lain, karena istilah murtad hanya ada dalam Islam.

Menurut Ulama Hanafiyyah, murtad memberanikan diri mengatakan dengan uca-pan yang menyebabkan kufur. Sedangkan menurut ulama Mailikiyah, yaitu muslim yang berpaling dari kekufuran baik dengan ucapan, niat maupun perbuatan. Menurut Salafi'iyyah dan Hambaliah, murtad yaitu memutus atau keluar dari Islam baik dengan niat, perbuatan maupun dengan perkataan. $^{70}$ Sebagaimana dengan agama-agama lain, ma-ka agama Islam menghadapi secara tegas ke-pada orang-orang yang keluar dari agama Is-lam. Bahkan orang yang keluar dari Islam dapat diancam dengan hukuman mati. Da-lam hal

${ }^{6}$ Wahbah, al-Fiqh al-Islầmi..., j-7, h. 728.

${ }^{70}$ Amir Syarifuddin, Hukum Perkawinan Islam di Indo-nesia, h. perkawinan, murtad juga menjadi alasan putusnya perkawinan tersebut. Para Imam sempat juga sependapat bahwa mur-tadnya salah seorang suami atau istri bisa menjadi alasan untuk bercerai.

J. Sebab yang Menjadikan Seseorang Murtad

Dalam kitab fiqh sunah diberikan con-toh-contoh yang menyebabkan kekafiran an-tara lain: ${ }^{71}$ 1. Mengingkari ajaran agama yang telah dituangkan secara pasti. Umpamanya keesaan Allah, mengingkari ciptaan Alah terhadap alam, mengingkari adanya malaikat, mengingkari kenabian Muhammad Saw, mengingkari Al-Quran sebagai wahyu Allah, mengingkari hari kebangkitan dan pembalasan, mengingkari kefarduan shalat, zakat, puasa, haji, syirik dan meninggalkan shalat.

2. Menghalalkan yang telah disepakati keharamannya. Umpamanya meng-halalkan minuman arak, zina, me-makan daging babi dan menghalal-kan membunuh orang-orang yang terjaga darahnya.

3. Menghalalkan apa yang telah disepakati, seperti mengharamkan memakan nasi.

4. Mencaci maki Nabi SAW, demikian juga bila mencaci NabiNabi Allah sebelumnya.

5. Mencaci maki agama Islam, mencela Al-Quran dan sunah Nabi, berpaling dari hukum yang ada dalam Al-Quran \& sunnah Nabi.

6. Mengaku bahwa wahyu Allah telah turun padanya. Ini tentu saja selain Nabi Muhammad.

7. Mencampakkan mashyaf Al-Quran atau kitab-kitab hadist ke tempat-tempat kotor atau 289.
${ }^{71}$ Sayyid Sabiq, Fiqh as-Sunnah, Juz:II, 288- 
menjijikkan se-bagai penghinaan dan mengang-gap enteng isinya.

K. Status Hukum Perkawinan Orang Murtad

Dalam Peraturan, UndangUndang mengatur mengenai murtad hanya spesifik pada perkara murtad yang bisa menjadi alasan perceraian sesuai dengan Pasal 75 KHI (Kompilasi Hukum Islam) mengenai keputusan:

1. Perkawinan yang batal karena salah satu suami atau istri murtad.

2. Anak-anak yang dilahirkan dari per-kawinan tersebut.

3. Pihak ketiga sepanjang mereka me-mperoleh hak-hak dengan beritikad baik, sebelum keputusan pembata-lan perkawinan kekuatan hukum yang tetap. Mengenai murtad dapat men-jadi alasan-alasan perceraian sebagaimana yang diatur juga dalam Kompilasi Hukum Islam Pasal 116 huruf $\mathrm{k}$ "peralihan agama atau mur-tad yang menyebabkan terjadinya ketidakrukunan dalam rumah tangga.

L. Putusnya Perkawinan Karena Murtad Putusnya perkawian karena fasakh memiliki aki-bat hukum khusus yaitu tidak ada rujuk atau dalam pengertian lain suami tidak boleh rujuk pada mantan istri selama istri menjalani masa iddah, oleh karena perce-raian dalam bentuk fasakh berstatus bain sugra. Bila mantan suami dan mantan istri berkeinginan untuk memperbaiki hubu-ngan pernikahannya, mereka harus melaku-kan akad nikah yang baru, baik dalam waktu masa mantan istri menjalani masa iddah dari mantan suaminya itu atau nanti setelah sele-sainya masa iddah. Akibat lain dari per-ceraian fasakh adalah tidak mengurangi bilangan talak. Artinya hak suami berupa hak untuk mentalak istrinya maksimal tiga kali tidak berkurang dengan adanya fasakh. Talak terbagi menjadi bain dan raj'i. Talak raj'i tidak mengakhiri ikatan pernikahan secara langsung, sedangkan talak bain me-ngakhiri pernikahan seketika itu. ${ }^{72}$ Akibat hukum yang terjadi setelah ikrar talak, yaitu: hubungan antara suami istri putus, istri mempunyai hak iddah selama 3 bulan dan dapat dilaksanakan pembagian harta bersama, adanya hak pemeliharaan anak atau ha-dhanah. Bilamana perkawinan putus karena talak, maka bekas suami wajib:

1. Memberi mut'ah pada bekas istrinya, baik berupa uang maupun benda, kecuali bekas istri tersebut qabla ad-dukhul.

2. Memberi nafkah, maskan dan kiswah bekas istri selama dalam iddah, kecuali bekasistri telah di jatuhi ta-lak ba'in atau nusyuz dan dalam keadaan tidak hamil.

3. Melunasi mahar yang masih terhutang seluruhnya, dan separuh apabila qobla aldukhul

4. Memberikan biaya hadhanah untuk anak-anaknya yang belum mencapai umur 21 tahun.

Dalam Pasal 41 UndangUndang No-mor 1 Tahun 1974 Tentang Perkawinan di-jelaskan juga mengenai akibat putusnya ka-rena perceraian ialah:

1. Baik ibu atau bapak tetap berkewajiban memelihara dan mendidik anak-anaknya, semata-mata berdasarkan kepentingan anak, bilamana ada perselisihan mengenai pengua-

\footnotetext{
${ }^{72}$ Satria Effendi, M. Zein, Problematika Hukum Keluarga Islam Kontemporer. Kencana, Jakarta, 2004, h.48
} 
saan anak-anak, Pengadilan memberi keputusan.

2. Bapak yang bertanggung jawab atas semua biaya pemeliharaan dan pen-didikan yang diperlukan anak itu, bilamana bapak dalam kenyataan-nya tidak dapat memberi kewaji-ban. Pengadilan dapat menentukan bahwa ikut memikul biaya tersebut.

3. Pengadilan dapat mewajibkan kepa-da bekas suami untuk memberikan biaya penghidupan dan/atau menentukan sesuatu kewajiban bagi bekas istri.

Jika salah satu dari suami istri murtad maka pernikahan keduanya secara otomatis fasakh, tanpa membutuhkan Putusan Maje-lis Hakim untuk memisahkan keduanya, jika yang murtad kembali Islam maka mereka tetap dalam pernikahan sebelumnya, begitu pula sebaliknya. ${ }^{73}$ Menurut Pasal 71 KHI (Kompilasi Hukum Islam) yang menyatakan bahwa suatu perkawinan dapat dibatalkan apabila:

1. Seorang suami melakukan poligami tanpa izin Pengadilan Agama.

2. Perempuan yang dikawini ternyata kemudian diketahui masih menjadi istri pria lain yang mafqud.

3. Perempuan yang dikawini ternyata masih da-lam iddah dan suami lain.

4. Perkawinan yang melanggar batas umur perkawinan sebagaimana ditetapkan pada Pasal 7 UndangUndang Nomor 1 Tahun 1974.

5. Perkawinan dilangsungkan tanpa wali atau di laksanakan oleh wali yang tidak berhak.

${ }^{73}$ Hasan Saleh, Kajian Fiqh Nabawi dan Fiqh Kontem-porer, (Jakarta: PT Rajawali Pers, 2008), h.322
6. Perkawinan yang dilaksanakan de-ngan paksaan.

Pada Pasal 75 KHI

(Kompilasi Hu-kum Islam) juga dijelaskan bahwa keputusan pembatalan perkawinan tidak berlaku surut terhadap:

1. Perkawinan yang batal karena salah satu sumai atau istri murtad.

2. Anak-anak yang dilahirkan dari perkawinan tersebut.

3. Pihak ketiga sepanjang mereka memperoleh hak-hak dengan beritikad baik, sebelum keputusan pembatalan perkawinan kekuatan hukum yang tetap;

Berdasarkan dalam Pasal 116

KHI (Kompilasi Hukum Islam) adalah sebagai berikut:

1. Salah satu pihak berbuat zina atau menjadi pemabuk, pemadat, penjudi dan lain sebagai-nya yang sukar disembuhkan.

2. Salah satu pihak mninggalkan pihak lain selama 2 (dua) Tahun berturut-turut tanpa izin pi-hak lain dan tanpa alasan yang sah atau kare-na hal lain diluar kemampuannya.

3. Salah satu pihak mendapat hukuman penjara 5 (lima) tahun atau hukuman yang lebih berat setelah perkawinan berlangsung.

4. Salah satu pihak melakukan kekejaman atau penganiayaan berat yang membahayakan pihak lain.

5. Salah satu pihak mendapat cacat badan atau penyakit dengan akibat tidak dapat menjalankan kewajibannya sebagai suami atau istri.

6. Antara suami dan istri terus menerus teijadi perselisihan dan pertengkaran dan tidak ada harapan akan hidup rukun lagi dalam rumah tangga.

7. Suami menlanggar taklik talak. 
8. Peralihan agama atau murtad yang menye-babkan terjadinya ketidakrukunan dalam ru-mah tangga ${ }^{74}$

M. Pelaksanaan Eksekusi Hak Asuh Anak (Hadhanab) Terhadap Isteri Murtad Dalam Perkara Nomor. 398/Pdt.G/ 2013/ PA.Pbr Di Pengadilan Agama Pekanbaru

$$
\text { Berdasarkan Penetapan }
$$

Putusan Per-kara Nomor. 398/Pdt.G/2013/PA.Pbr ta-nggal 7 Mei 2013 dan Surat Permohonan Penggugat/Pemohon Eksekusi Tanggal 02 September 2013 yang maksudnya Tergugat/ Termohon Eksekusi belum memenuhi isi putusan tersebut, dimana dalam perkara Jonel Amran Bin Amran umur 43 tahun, Pekerjaan Karyawan Swasta, Agama Islam, bertempat tinggal di Jalan Pramuka No 9 RT 01 RW 01 Kelurahan Lembah Asri Kecama-tan Rumbai Pesisir Kota Pekanbaru, Kodya Pekanbaru, sebagai Penggugat/Pemohon Eksekusi dan lawannya adalah Ita Asnita Binti Abd Majid, umur 40 tahun, Pekerjaan Wiraswasta, Agama Kristen bertempat ting-gal di Jalan Sembilang Komplek Gardunia Perumahan Chevron Nomor 310 Kelurahan Lembah Damai Kec. Rumbai Pesisir Pekan-baru Kodya Pekanbaru, sebagai Tergugat/ Termohon Eksekusi.

Dalam hal ini yang telah mempunyai kekuatan hukum tetap, yang amar putusan-nya berbunyi sebagai berikut:

1. Menyatakan Tergugat telah dipanggil secara resmi dan patut untuk meng-hadap ke persidangan, tidak hadir;

2. Mengabulkan gugatan Penggugat de-ngan verstek;

\footnotetext{
${ }^{74} \mathrm{Ibid}$, Inpres No 1 tahun 1991.
}

3. Menetapkan keempat orang anak Pe-nggugat dan Tergugat yang masing-masing bernama:
a. Cindy Nelta Putri (perempuan), umur 20 tahun;
b. Bunga Shinta Bella (perempuan), umur 18 tahun;
c. Obed Edom JJ (laki-laki), umur 9 tahun;
d. Nicolas Gaspitaro JJ (laki-laki), umur 5 tahun;

4. Menghukum Tergugat untuk menye-rahkan keempat orang anak ter-sebut kepada Penggugat;

5. Membebankan kepada Penggugat un-tuk membayar seluruh biaya perkara yang hingga kini dihitung sebesar Rp. 466.000,-(empat ratus enam puluh en-am ribu rupiah);

Berdasarkan hal tersebut, Ketua Pe-ngadilan Agama Pekanbaru memerintahkan kepada Jurusita Pengadilan Agama Pekan-baru untuk memanggil Penggugat dan Ter-gugat untuk menghadap ke Persidangan di Pengadilan Agama Pekanbaru pada hari Se-nin tanggal 07 Oktober 2013 jam 14.30 WIB untuk dilakukan teguran dalam tempo 8 (delapan) hari agar ia mematuhi putusan ter-sebut.

Kemudian pada hari Kamis tanggal 26 Desember Panitera Jurusita melakukan Relas Panggilan Aanmaning ke I kepada Penggugat dan Ter-gugat untuk hadir dalam persidangan pada hari Senin tanggal 07 Oktober 2013 jam 14.30 WIB, Panitera Jurusita hanya bertemu dan berbicara dengan Penggugat, dan Panitera Jurusita tidak bertemu dengan Tergugat, sehingga Panitera Jurusita me-nyampaikan Relas Panggilan Aanmaning ke-pada Kelurahan untuk disampaikan kepada Tergugat. Selanjutnya pada hari Senin tanggal 07 Oktober 2013 jam 14.30 WIB, Pengadilan Agama Pekanbaru melakukan persidangan, pada saat 
persidangan dilaksa-nakan hanya dihadiri sendiri oleh Penggugat dan Tergugat tidak hadir. Untuk itu Ketua Pengadilan Agama menunda sidang sampai pada hari Senin tanggal 21 Oktober 2013 dan sidangpun dinyatakan ditutup. Kemudi-an Ketua Pengadilan Agama kembali memerintahkan kepada Panitera Jurusita untuk merelas Aanmaning kembali kepada Peng-gugat dan Tergugat.

Pada hari Rabu tanggal 16 Oktober 2013 Panitera Jurusita kembali melakukan Relas Panggilan Aanmaning ke II kepada Penggugat dan Ter-gugat untuk hadir dalam persidangan pada hari Senin tanggal 21 Ok-tober 2013 jam 14.30 WIB, nah pada Aan-maning ke II ini, Panitera Jurusita juga hanya bertemu dan berbicara dengan Penggugat, dan Panitera Jurusita tidak bertemu dengan Tergugat, sehingga Panitera Jurusita kembali menyampaikan Relas Aanmaning kepada Ke-lurahan untuk di sampaikan kepada yang bersangkutan. Kemudian pada hari Senin tanggal 21 Oktober 2013 jam 14.30 WIB, Pengadilan Agama Pekanbaru kembali me-lakukan persidangan, pada saat persidangan dilaksanakan juga hanya dihadiri sendiri oleh Pemohon dan Termohon tidak hadir sekali-pun dipanggil secara resmi, dan Ketua Pe-ngadilan Agama mengajukan beberapa per-tanyaan kepada Penggugat yang hadir dan menganjurkan kepada Penggugat agar mela-kukan pendekatan kepada empat orang anak menjelang eksekusi dilakukan, sehingga pada pelaksanaan eksekusi nanti tidak me-ngalami kesulitan.

Setelah itu, pada hari Selasa tanggal 25 November 2013 Panitera Ju-rusita kembali mengeluarkan Surat Pemberitahuan kepada Penggugat dan Tergugat bahwa pada hari Kamis tanggal 05 Desember 2013 jam 10.30 WIB, akan dilaksanakan proses eksekusi anak bertempat di Jalan Sembilang Kom-pleks Gardenia Perumahan Chevron Nomor 310 Kelurahan Lembah Damai Kecamatan Rumbai Pesisir, Kota Pekanbaru. Namun sa-ma halnya Panitera Jurusita hanya bertemu dengan Penggugat saja, dan Panitera Juru-sita tidak bertemu dengan Termohon, dan Panitera Jurusita menyampaikan Relas Pang-gilan kepada Pihak Kelurahan untuk disam-paikan kepada Tergugat.

Di samping itu pada tanggal 28 No-vember 2013 Tergugat melalui Kuasa Hu-kum/Pengacara menyampaikan Surat Pem-beritahuan Keberatan kepada Ketua Penga-dilan Agama Pekanbaru untuk tidak melakukan eksekusi terhadap 4 (empat) orang anak tersebut. Sebagaimana hal tersebut di sampaikan di dalam Surat berdasarkan Fak-ta-Fakta Hukum, Keberatan Alasan Hu-kum. adapun isi Suratnya antara lain sebagai berikut:

Fakta-Fakta Hukum :

1. Bahwa klien kami ibu Ita Asnita telah resmi bercerai dengan Jonel Amran Bin Amran berdasarkan alat bukti salinan putusan Pengadilan Agama Pekanbaru Nomor: 437/ Pdt.G/2010/PA.Pbr, tanggal 06 Oktober 2010 atas gugatan mantan suaminya Tuan Jonel Amran Bin Amran.

2. Bahwa atas gugatan Penggugat Tuan Jonel Amran ditujukan kepada klien kami dimana Penggugat tahu persis alamat kien kami yang sebenarnya dan Penggugat masih komunikasi via hand-phone, dan Penggugat sering datang ketempat tinggal klien kami baik di Jakarta maupun di Bandung untuk berte- 
mu anak-anak sepertinya tidak ada masalah diantara Penggugat dan Tergugat, karena Penggugat tidak jujur memberikan alamat di dalam gugatannya sehingga Tergugat benar-benar tidak mengetahui adanya gugatan cerai dari Penggugat (Jonel Amran Bin Amran) de-ngan bukti Tergugat baru mengetahui adanya perceraian pada tanggal 27 Agustus 2013 pada waktu pengambilan Sa-linan Putusan di Pengadilan Agama Pekanbaru bersama pengurus Ko-mnas Ham dari Kanwil Menkum Ham Provinsi Riau.

3. Bahwa akibat Penggugat memberikan alamat Tergugat tidak benar di dalam Gugatannya, maka semua Surat Panggilan dari Pengadilan Agama Pekanbaru tidak sampai kepada Tergugat hal ini dilakukan oleh Penggugat patut diduga agar semua isi gugatannya dikabulkan oleh Pengadilan Agama Pekanbaru seperti bukti sesuai (empat) orang anak tersebut dibiayai oleh klien kami dan semua anak-anak tinggal bersama atau diasuh oleh ibu Ita Asnita.

Keberatan dan Alasan Hukum

Tentang Keberatan:

1. Bahwa akibat ketidakjujuran Penggugat membuat alamat Tergu-gat di dalam gugatannya, maka klien kami merasa keberatan sebagian isi pu-tusan Pengadilan Agama Pekanbaru Nomor: 437/ Pdt.G/2010/PA.Pbr, tanggal 06 Oktober $2010 \quad$ khusus-nya menghukum poin ke 4 (empat) dalam amar putusan mengatakan "menghukum Tergugat untuk menyerahkan keempat orang anaknya tersebut kepada Penggugat.

2. Bahwa akibat ketidakjujuran Penggugat mencantumkan alamat Tergugat di dalam gugatannya, padahal Penggugat mengetahui persis ala-mat Tergugat yang sebenarnya ma-ka apa yang diputuskan oleh Penga-dilan Agama Pekanbaru menurut ketentuan hukum adalah cacat hukum dan/atau batal demi hukum.

Tentang Alasan Hukum:

1. Bahwa dengan adanya penetapan Pengadilan Agama Pekanbaru tentang Relas Pemberitahuan Eksekusi Nomor: 398/Pdt.G/2013/ PA.Pbr tanggal 25 November 2013, bahwa pada tanggal 05 De-sember 2013 jam 10.30 Wib akan dilaksanakan eksekusi anak di Jl. Sembilang Komplek Chevron Nomor 310, Kelurahan Lembah Damai Rumbai Pesisir, Kota Pekanbaru.

2. Bahwa perlu diketahui ke 4 (empat) orang anak klien kami selama ini ibu Ita Asnita sejak tahun 2009 sampai dengan sekarang ini tetap tinggal bersama dan termasuk selu-ruh biaya anakanak sehari-hari tetap ditanggung oleh klien kami dan yang sangat perlu diperhatikan adalah kepentingan anak-anak yang diasuh oleh ibu kandungnya sendiri karena ke 4 (empat) anak tersebut masih di bawah umur yang me-merlukan kasih sayang dari seorang ibu ter-hadap anakanak agar tidak terpukul mentalnya, jika mereka di pisahkan antara anak-anak dan ibu kandungnya sendiri secara psikologi akan berakibat kepada mentalisasi anak-anak baik jasmani dengan rohani.

3. Bahwa untuk itu kami mohon kepada Ketua Pengadilan Agama Pekanbaru, mempertimbangkan dan mengedepankan kepenting-an ke 4 (empat) orang anak klien kami daripada mengedepankan kepenti- 
ngan hukum, kecuali klien kami tidak sanggup untuk membiayai selu-ruh kebutuhan ke 4 (empat) orang anak tersebut dan ditelantarkan ol-eh ibu Ita Asnita barulah dilakukan eksekusi terhadap anak-anak.

4. Bahwa atas dasar pertimbangan ke-manusiaan dan mental ke 4 (empat) orang anak klien kami, kami mo-hon untuk tidak melakukan ekse-kusi terhadap anak-anak klien kami, sebab menurut ketentuan hukum yang berlaku di indonesia bila se-orang anak atau lebih jika terjadi perceraian antara suami isteri anakanak masih di bawah umur akan di asuh oleh ibu kandungnya, kecuali salah seorang suami isteri itu cacat mental tidak dapat mengasuh anak dengan sempurna barulah perwalian mengasuh jatuh kepada yang sehat rohani dan jasmani, oleh karena itu mengingat ke 4 (empat) orang anak klien kami semuanya masih di bawah umur yang memer-lukan kasih sayang dari seorang ibu kandungnya untuk itu, mohon un-tuk tidak melakukan eksekusi terha-dap anak-anak, demi kesejahteraan ibu dan anak serta kepentingan pendidikan semua anak klien kami. Demikian surat ini dibuat, kuasanya J.Marbun, SH.MH ditandatangani.

Disisi lain, Pengadilan Agama

Pekan-baru terus melakukan upaya hukum dalam melakukan pelaksanaan eksekusi hak asuh anak tersebut, guna memenuhi isi daripada Putusan Perkara Nomor: 398/Pdt.G/2013/ PA.Pbr, dengan menimbang bahwa permo-honan tersebut adalah berdasarkan hukum dan karenanya dapat di kabulkan. Dengan memperhatikan hal tersebut dan segala ke-tentuan Peraturan
Perundang-Undangan ya-ng berkaitan pada perkara ini, maka Ketua Pengadilan Agama Pekanbaru memerin-tahkan Panitera/Jurusita Pengadilan Agama Pekanbaru disertai dengan 2 (dua) orang sak-si dan menyurati Aparat Keamanan (Polisi) dan Kelurahan bahwa akan dilaksanakan eksekusi sesuai isi putusan tersebut.

Berdasarkan penetapan Ketua Penga-dilan Agama Kelas I.A Pekanbaru tanggal 18 November 2013 memerintahkan kepada Panitera Pengadilan Agama Kelas I.A Pekan-baru untuk melakukan eksekusi anak dan Panitera memberitahukan Kepada Penggu-gat maupun Tergugat bahwa pada hari Kam-is tanggal 05 Desember 2013 jam 10.30 WIB akan dilakukan eksekusi anak bertempat di Jalan Sembilang Kompleks Gardenia Perumahan Chevron Nomor 310 Kelurahan Lembah Damai Kecamatan Rumbai Pesisir, Kota Pekanbaru.

Setelah kepadanya diberitahukan ten-tang maksud kedatangan Pani-tera Jurusita dengan memperlihatkan Surat Penetapan untuk melakukan eksekusi 4 (empat) orang anak dan disaksikan oleh 2 (dua) orang saksi. Sewaktu pelaksanaan eksekusi anak dilaksanakan, anak-anak yang ditemukan di lapa-ngan antara lain, sebagai berikut:

1. Cindy Nelta Putri (perempuan), umur 20 tahun;

2. Bunga Shinta Bella (perempuan), umur 18 tahun;

3. Obed Edom JJ (laki-laki), umur 9 tahun;

4. Nicolas Gaspitaro JJ (laki-laki), umur 5 tahun;

Dengan menimbang, bahwa sewaktu dilakukan eksekusi dilaksanakan, ke-empat orang anak 
tersebut mengadakan perlawanan karena tidak bersedia di eksekusi, dan tetap memilih untuk ikut bersama ibunya (Ter-mohon eksekusi), maka eksekusi ditunda dan/atau dicabut sampai waktu yang akan ditentukan kemudian.

Oleh karena itu, melihat pada saat pe-laksanaan eksekusi mengalami kegagalan, dikarenakan keempat orang anak tersebut tidak bersedia di eksekusi, dan tetap memilih untuk ikut bersama ibunya (Termohon eksekusi), maka eksekusi di cabut oleh Peng-gugat/Pemohon eksekusi.

N. Penyelesaian Akhir Atas Permohonan Eksekusi Hak Asuh Anak (Hadhanah) Terhadap Istri Murtad) Dalam Perkara Nomor. 398/Pdt.G/2013/PA.Pbr Di Pengadilan Agama Pekanbaru.

Dalam Putusan Perkara Nomor. 398/ Pdt.G/2013/PA.Pbr di Pengadilan Agama Pekanbaru Tentang Hak Asuh Anak (ha-dhanah) Antara Jonel Amran Bin Amran umur 43 tahun, selaku Penggugat dan lawannya adalah Ita Asnita Binti Abd Majid, umur 40 tahun, sebagai Tergugat. Dengan penelusuran dan melihat berbagai fakta-fakta yang ada, juga berdasarkan pertimbangan hukum yang berlaku di Indonesia, bahwa jika salah satu syarat pemegang hak asuh anak (hadhanah) yang tidak terpe-nuhi oleh salah satu pihak, maka gugurlah hak asuh anak (hadhanah) tersebut, sebagaimana dalam Perkara Nomor. 398/Pdt.G/2013/PA. Pbr tersebut, dimana Pengadilan Agama Pekanbaru telah mengadili dan memutuskan yang mana telah mempunyai kekuatan hu-kum tetap yang amar putusan nya berbunyi sebagai berikut:
1. Menyatakan Tergugat telah dipang-gil secara resmi dan patut untuk menghadap ke persidangan, tidak hadir;

2. Mengabulkan gugatan Penggugat dengan verstek;

3. Menetapkan keempat orang anak Penggugat dan Tergugat yang masing-masing bernama:

a. Cindy Nelta Putri (perempuan), umur 20 tahun;

b. Bunga Shinta Bella (perempuan), umur 18 tahun;

c. Obed Edom JJ (laki-laki), umur 9 tahun;

d. Nicolas Gaspitaro JJ (laki-laki), umur 5 tahun;

4. Menghukum Tergugat untuk menyerahkan keempat orang anak tersebut kepada Penggugat;

5. Membebankan kepada Penggugat untuk membayar seluruh biaya per-kara yang hingga kini dihitung se-besar Rp. 466.000,- (empat ratus enam puluh enam ribu rupiah);

Namun ketika proses pelaksanaan ek-sekusi tersebut dilakukan, di temukan ke-empat orang anak tersebut dan ternyata keempat orang anak ini mengadakan perla-wanan karena tidak bersedia untuk di ekse-kusi, dan tetap memilih untuk ikut bersama ibunya (Tergugat/Termohon eksekusi), dan tidak bersedia ikut bersama ayahnya (Peng-gugat/Pemohon eksekusi) dari anak-anak tersebut. Oleh karena gagal pada saat pelak-sanaan eksekusi, maka eksekusi di cabut oleh Penggugat/Pemohon eksekusi.

Jadi berdasarkan penjelasan di atas, dapat dianalisa bahwa Panitera Jurusita Pe-ngadilan Agama Pekanbaru dengan dihadiri oleh 2 orang saksi, Aparat Keamanan (Polisi), Penggugat/Pemohon, Tergugat/ Ter-mohon, sudah melaksanakan 
proses pelak-sanaan eksekusi atas perintah putusan per-kara tersebut, namun dikarenakan beberapa faktor antara lain; kedekatan psikologis anak dengan ibunya, walaupun ibunya telah ber-pindah agama (murtad). Hal ini memang sangat sulit menurut Penulis untuk di laku-kan, walaupun Negara kita merupakan Ne-gara Hukum, namun harus juga memper-hatikan psikoligis anak, jika terus dipaksakan bisa berakibat fatal pada mental si anak tersebut. Maka jalan satusatunya dengan menunggu dan meluangkan waktu agar anak tersebut bisa mengerti agama, dan mana ya-ng terbaik untuk ia memilih apakah mengi-kuti ayah atau mengikuti ibu.

Dengan

demikian, penyelesaikan akhir perkara dalam kasus tersebut ditunda sampai setelah anak tersebut mumayyiz dan diserahkan pada anak untuk memilih ayah atau ibunya sebagai pemegang hak pemelihara-annya.

Di samping itu, menurut Aris Bintania (dalam jurnal media neliti, 2009:2) Perkara-perkara di bidang perkawinan, dalam hal ini perebutan hak asuh anak (hadhanah), merupakan sengketa keluarga yang memer-lukan penanganan khusus sesuai dengan amanat Undangundang Perkawinan. Peris-tiwa perceraian tidak jarang mengakibatkan terlantarnya pengasuhan anak. Tidak jarang terjadi perebutan mengenai hak asuh anak, masing-masing bekas suami isteri merasa paling berhak dan paling layak untuk men-jalankan hak asuh anak. ${ }^{75}$

Pemeliharaan anak (Hadhanah) adalah kegiatan mengasuh, memelihara dan mendi-dik anak hingga dewasa atau mampu

${ }^{75}$ Satria Effendi, Problematika Hukum Keluarga Islam Kontemporer, (cet-2, Kencana, Jakarta, 2004), hal. 166-7. berdiri sendiri. ${ }^{76}$ Suami isteri memikul kewajiban untuk mengasuh dan memelihara anak-anak mereka, pertumbuhan jasmani, rohani, kecerdasan dan pendidikan agamanya. ${ }^{77}$ Se-orang suami, sesuai penghasilannya, mena-nggung biaya rumah tangga, perawatan, pengobatan dan pendidikan anak. ${ }^{78}$

Kewajiban orang tua berlaku sampai anak itu kawin atau dapat berdiri sendiri, dan kewajiban itu terus berlaku meskipun perkawinan kedua orang tua putus. ${ }^{79}$ Batas usia anak yang mampu berdiri sendiri/ de-wasa adalah 21 tahun, sepanjang anak tidak cacat fisik/mental dan belum kawin. ${ }^{80}$ Semua biaya penyusuan anak dipertanggungjawab-kan kepada ayahnya, bila sudah meninggal, dibebankan kepada orang yang berkewajiban menafkahi ayah atau walinya. ${ }^{81} \mathrm{Jika}$ terjadi perceraian, pemeliha-raan anak yang belum mumayyiz (belum 12 tahun) adalah hak ibunya, setelah mumayyiz diserahkan pada anak untuk memilih ayah atau ibunya sebagai pemegang hak pemeliharaannya. Sedangkan biaya pemeliharaan tetap ditanggung oleh ayahnya. ${ }^{82}$ Semua biaya hadhanah dan nafkah anak tetap merupakan kewajiban ayah sesuai kemampuannya terhadap anak-anaknya yang belum berusia 21 tahun. $^{83}$

Kewajiban dan tanggung jawab orang tua, sesuai ketentuan Pasal 26 UU. Per-lindungan Anak,

${ }^{76}$ Ketentuan Umum Pasal 1 huruf $g$ Inpres No. 1/1991 tentang Kompilasi Hukum Islam

\author{
${ }^{77}$ Pasal 77 ayat (3) KHI \\ ${ }^{78}$ Pasal 80 ayat (4 b-c) KHI \\ ${ }^{79}$ Pasal 45 UU. Perkawinan \\ ${ }^{80}$ Pasal 98 ayat (1) KHI \\ ${ }^{81}$ Pasal 104 KHI \\ 82Pasal $105 \mathrm{KHI}$ \\ ${ }^{83}$ Pasal 149 huruf d KHI dan Pasal 156
} huruf d; Pasal 41 UU. Perkawinan 
adalah untuk mengasuh, memelihara, mendidik dan melindunginya. Menumbuhkembangkan sesuai kemampuan, bakat dan minatnya dan mencegah terjadinya perkawinan usia dini. Apabila orang tua tidak ada atau karena suatu sebab tidak dapat melaksanakan kewajiban dan tanggungja-wabnya, kewajiban itu dapat dialihkan ke ke-luarga. Namun bila orang tua justru me-lalaikan kewajibannya, dapat dilakukan tindakan pengawasan bahkan kuasa orang tua dapat dicabut melalui penetapan pe-ngadilan. ${ }^{84}$ Permohonan penetapan penga-dilan ini dapat dimintakan oleh salah satu orang tua, saudara kandung atau keluarga sampai derajat ketiga. Pencabutan kuasa orang tua dapat juga di ajukan oleh pejabat atau lembaga yang berwenang, selanjutnya Pengadilan dapat menunjuk orang (harus seagama) atau lembaga pemerintah/ masya-rakat sebagai walinya. Penetapan itu juga harus memuat pernyataan bahwa perwalian tidak memutus hubungan darah antara anak dengan orang tua kandungnya atau menghi-langkan kewajiban orang tua untuk membia-yai anaknya dan adanya penyebutan batas waktu pencabutan. ${ }^{85}$

Antara asas penyelenggaraan perlin-dungan anak adalah asas kepentingan ter-baik bagi anak, artinya dalam semua tindakan menyangkut dirinya maka kepentingan ter-baik baginya harus menjadi pertimbangan utama. ${ }^{86}$ Mengenai penyelenggaraan perlindu-ngan terhadap agama anak, Negara, peme-rintah, masyarakat,

\footnotetext{
${ }^{84}$ Pasal 30 UU. Perlindungan Anak

${ }^{85}$ Pasal 31 dan 32 UU. Perlindungan

Anak.'

${ }^{86}$ Pasal 2 dan Penjelasannya, UU. Perlindungan Anak
}

keluarga, orang tua, wali dan lembaga sosial harus menjamin setiap anak untuk beribadah menurut agamanya dan sebelum anak dapat menentukan pili-hannya, disesuaikan dengan agama orang tuanya. Perlindungan meliputi pembinaan, pembimbingan dan pengamalan ajaran aga-ma. ${ }^{87}$ Anak dapat menentukan agama pilihan-nya setelah ia berakal dan bertanggung jawab serta memenuhi syarat dan tatacara sesuai ketentuan agama pilihannya dan Ketentuan UndangUndang. ${ }^{88}$

Demi kepastian hukum, persoalan ini perlu ada kejelasan hukumnya dengan me-revisi dan melengkapi pasal dan aturan yang lengkap dan jelas dalam Undangundang Perlindungan Anak. Mengenai pelaksanaan eksekusi hak asuh anak (hadhanah) terhadap isteri yang keluar dari agama islam (murtad), yang menjadi tema utama penelitian ini, Pe-ngadilan Agama berwenang memutuskan hak pengasuhan jatuh ke tangan penggugat. Karena pernikahan dilangsungkan di Kantor Urusan Agama yang berarti menikah secara Islam. Adapun mengenai apakah si isteri yang murtad berhak mengasuh anaknya setelah bercerai, maka yang menjadi dasar hukum tentu hukum positif yang berlaku di Pengadilan Agama yang kebanyakan berasal dari hukum material Islam, dan jika tidak ditemukan pengaturannya maka hakim ber-wenang melakukan pencarian dan pengga-lian hukum sesuai dengan kaidah penggalian hukum yang berasal dari nilai-nilai dan norma-norma hukum nasional, hukum adat, ilmu pengetahuan dan

\footnotetext{
${ }^{87}$ Pasal 42-3 UU. Perlindungan Anak.

${ }^{88}$ Penjelasan Pasal 42 ayat (2) UU. Perlindungan Anak.
} 
sumber-sumber hu-kum agama Islam yang berasal dari kitab-kitab fiqh.

Dari pernyataan Peraturan Perundang-Undangan pada bagian II, tampaknya keten-tuan mengenai hak asuh anak pengaturannya masih minim dan kurang lengkap. Paling tidak, ada beberapa hal yang menjadi catatan sebagaimana yang dikatakan Aris Bintania (dalam Jurnal media neliti, 2019:12):

Pertama: berdasarkan pernyataan KHI, jika terjadi perceraian, pemeliharaan anak yang belum tamyiz, yaitu belum berusia 12 tahun, adalah hak ibunya. Tampaknya ke-tentuan ini bersifat mutlak sehingga setiap anak yang belum berusia 12 tahun mesti dalam pemeliharaan ibunya, kecuali ibunya tiada maka dialihkan ke pemegang hadhanah yang lain. Jadi yang berhak hadhanah perta-ma mutlak pada ibunya, tanpa memandang agama si ibu. Mengenai ketentuan ini pun seharusnya KHI perlu menegaskan posisinya dalam hal ini jika memang tidak ada per-bedaan hak ibu dalam hadhanah dari segi agama. Mengingat dalam hukum Islam, ter-jadi perselisihan pendapat apakah ibu non-muslim berhak menjalankan hadhanah anak yang Islam. Sebagaimana kejelasan dalam KHI mengenai batas usia tamyiz yang secara tegas dinyatakan 12 tahun, meskipun para ulama fiqh menetapkan usia yang varatif dari 7 , 8, 9 sampai 11 tahun tanpa ada kejelasan waktu berakhirnya selain keadaan anak sudah dapat berdiri sendiri, KHI membuat batasan yang melampaui semua itu dengan menyatakan berumur 12 tahun dan berakhir sampai usia 21 tahun.

Kedua, KHI menyatakan
bahwa jika ternyata
hadhanah tidak dapat menjamin

keselamatan jasmani dan rohani anak, maka Pengadilan Agama dapat memin-dahkan hak hadhanah atas permintaan kera-bat yang juga punya hak hadhanah. Apa yang dimaksud dengan tidak dapat menjamin keselamatan jasmani dan rohani anak, apa-kah ibu yang murtad dapat dikualifikasikan sebagai ancaman terhadap keselamatan rohani anak, sayangnya tidak ada penjelasan dalam ketentuan ini, sehingga jaminan terhadap keselamatan jasmani dan rohani anak bersifat multi tafsir dan sangat relatif, ter-gantung penafsiran dan pemahaman hakim. Ketentuan ini dapat saja dijadikan dasar oleh hakim untuk meniadakan hak ibu yang mur-tad atas hadhanah dengan alasan mengan-cam keselamatan rohani anak, namun begitu tentu akan bertentangan dengan pernyataan bahwa jika orang tua bercerai maka peme-liharaan anak yang belum tamyiz adalah hak ibunya.

Dengan demikian, dapat dianalisa bah-wa sudah sewajarnya jika Peraturan Perun-dang-Undangan yang berlaku di Indonesia, meskipun untuk lingkungan Pengadilan Agama yang notabene merupakan peradi-lan bagi umat Islam, tidak membedabedakan hak warganegara dari segi agama penganut-nya, karena pembentukan suatu Peraturan Perundang-Undangan di negara yang berda-sarkan hukum harus didasari oleh sema-ngat bernegara dan semangat kebersamaan dalam perbedaan, tanpa ada diskriminasi hukum terhadap siapapun baik karena suku, bangsa, agama dan jenis kelamin. Namun demikian, juga perlu kepastian hukum dan pengaturan-nya dalam hal terjadinya perpindahan agama serta akibat-akibat hukum terhadap hak dan kewajiban dirinya dan yang menyangkut orang lain, 
termasuk terhadap suami dan anakanak yang dilahirkan sebagai akibat perkawinan.

Sementara menurut hukum Islam, ber-dasarkan penelusuran penda-pat-pendapat para ulama fiqh, (dalam Aris Bintania, 20-19:13) ternyata secara umum mereka terbagi kepada dua pendapat:

1. Non-Muslim tidak berhak menjalan-kan hadhanah.

Yaitu dari kalangan Syafi'iyah dan Hanabilah mensyaratkan yang menjalankan hadhanah harus beragama Islam. Menurut Muhyiddin al-Nawawi, hadhanah orang kafir tidak dapat mewujudkan kesejahteraan anak, justru akan merusak agamanya dan itu mudharat yang paling besar. Menurutnya hadis Nabi yang menyerahkan pada pilihan anak antara orang tua yang muslim dan kafir yang telah dijadikan dasar oleh Abu Hanifah, Ibnu Qasim alMaliky dan Abu Tsaur telah dimansukh. Menurut Ibnu Taimiyah sema-ngat syarak berkehendak menjaga kemasla-hatan anak sehingga putusan hukum pun adalah untuk kemaslahatan dunia dan akhi-rat. Menurut al-'Imrany tujuan kebahagiaan anak tidak akan wujud pada orang kafir, tidak dapat dipercaya dia tidak akan mempengaruhi dan merusak agamanya, ia berpan-dangan hadis ini tidak begitu dikenal dikala-ngan penukil hadis, jikapun benar maka mestilah Nabi sudah tahu si anak bakal me-milih bapaknya makanya Nabi menyuruhnya memilih, jadi hadis ini khusus untuk si anak tidak dalam kasus yang lain. Begitu juga menurut al-Sayyid al-Sẫbiq, wanita non-muslim tidak berhak hadha-nah.

2. Non-Muslim Berhak Menjalankan Ha-dhanah
Hanafiyah dan Malikiyah tidak men-syaratkan Islam, pemegang hadhanah boleh abl al-kitâb atau agama lain baik ibunya atau yang lain. Pendapat ini didasarkan pada riwa-yat Abu Dawud dan periwayat lain bahwa Nabi SAW menyerahkan pada pilihan anak untuk memilih antara bapaknya yang muslim dan ibunya yang kafir. Selain itu menurut pendapat ini, kasih sayang dalam hadhanah tidak akan berbeda dengan perbedaan aga-ma.

Menurut Zakariya al-Anshary, hadha-nah ibu yang kafir dapat di terima karena hak hadhanah itu memang miliknya. Menu-rut Abu Sa'id al-Istakhri, boleh diserahkan ke orang kafir berdasarkan riwayat Abdul Hamid ibn Salamah. Menurut al-Istakhri, ibu kafir zimmi lebih berhak atas anak daripada bapaknya yang muslim sampai anak berusia 7 tahun, begitu juga anak kafir zimmi, ibu lebih berhak atasnya. Menurut alSayyid al-Sẫbiq, golongan yang memboleh-kan hadha-nah wanita kafir beralasan ha-dhanah tidak lebih dari menyusui dan mela-yani yang tentu boleh di lakukan oleh wanita kafir. Meskipun begitu golongan Hanafi mensya-ratkan kafirnya bukan karena murtad, sebab orang kafir karena murtad dapat dipenjara sampai ia taubat dan kembali dalam Islam atau mati dalam penjara, sehingga ia tidak boleh diberi kesempatan mengasuh anak kecil, kecuali bila ia sudah taubat dan kem-bali ke Islam.

Dua pendapat kalangan ulama yang saling bertentangan ini, sebenarnya disebab-kan berbedanya interpretasi terhadap hadis Nabi yang memberi pilihan kepada anak un-tuk memilih antara bapaknya yang muslim dan ibunya yang kafir. Bagi yang memboleh-kan hadhanah wanita kafir atas anak muslim, hadis ini merupakan bukti tak terbantahkan 
bahwa Nabi sendiri memberi kesempatan kepada anak untuk memilih ibunya yang ka-fir, dan ketika anak sudah dapat menentu-kan, hadhanah merupa-kan hak anak.

Di samping itu hadis Nabi ini konteks-nya mengenai orang nonmus-lim yang ma-suk Islam terkait isteri dan anaknya, faktanya yang pindah agama adalah bapak sementara isterinya enggan, artinya ikatan perkawinan antara keduanya didasarkan pada keyakinan sebelumnya dan anak tersebut merupakan hasil dari ikatan perkawinan itu, sehingga sewajar-nya bila Nabi memberi kemung-kinan pada si anak untuk memilih ibunya yang sejak dahulu memang wanita kafir karena bapaknya dahulu juga kafir bahkan si anak sebenarnya adalah anak orang kafir. Bahwa si anak dan ibunya tidak ada kemes-tian untuk tunduk dan terikat dengan hukum Islam karena mereka kafir zimmi.

Persoalannya, kalangan ulama yang berpendapat ibu kafir tidak berhak hadhanah atas anak muslim, sudah terlanjur meman-dang si anak adalah muslim hanya karena bapaknya masuk Islam, padahal si anak asal-nya adalah anak orang kafir yang bapaknya masuk Islam, tentu lah si anak sebelum menyatakan keislamannya atau sebelum ia sampai usia beragama harus dianggap nonmuslim.

Berbeda persoalannya jika salah satu dari suami isteri muslim masuk ke agama lain yang dalam Islam diistilahkan murtad, sebagaimana kasus dalam putusan Pengadi-lan Agama Pekanbaru yang ditelaah dalam pene-litian ini, maka dalam hal ini yang bera-lih agama adalah ibunya sementara bapak tetap pada agama sebelumnya yaitu Islam.
Karena perkawinan mereka dilaksanakan se-cara Islam dan dahulu sewaktu melangsung-kan pernikahan keduanya Islam, maka si anak merupakan buah dari ikatan per-kawinan Islam sehingga dia harus dianggap sebagai anak orang Islam sampai ia dapat menentukan pilihan agamanya. Anak dan bapaknya tunduk kepada hukum Islam, bah-kan dalam Islam murtad adalah perbuatan tercela dan orang Islam yang murtad juga ada sanksi hukumnya sehingga wajar jika mayoritas ulama, bahkan Imam Hanafi sen-diri, berpendapat wanita atau orang murtad tidak berhak menjalankan hadhanah.

Di dalam hukum Islam, hal ini di namakan dengan dalil hukum istishab (teori kelangsungan hukum), bahwa status hukum suatu hal di masa lalu terus berlangsung pada masa kini dan masa depan sejauh belum ada perubahan terhadap status hukum tersebut atau sejauh belum ada dalil yang menentu-kan lain, yang dirumuskan dalam kaidah hukum Islam:

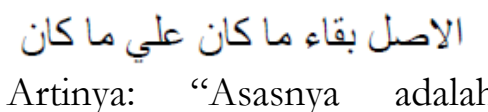
tetapnya se-suatu yang telah ada itu sebagaimana ada-nya" 89

Meskipun Pengadilan Agama tidak berwenang mengadili perkara selain di antara orang-orang Islam, dan meskipun si ibu pindah agama tetapi karena pernikahan di lakukan di Kantor Urusan Agama dan bukan di Catatan Sipil maka tentulah Pengadilan Agama yang berwenang sehingga penentuan hadhanah anak juga harus tunduk kepada hukum positif yang berasal dari hukum

${ }^{89} \mathrm{Al}$-Zarqa', Syarb al-Qawấid al-Fiqhiyah, Dar al-Garb al-Islamy, 1983. Ttp. h. 43.; Lihat juga Syamsul An-war, Prof.Dr, Hukum Perjanjian Syari'ah (Studi Tentang Teori Akad dalam Figh Muamalat, ed-1, Jakarta, Raja Grafindo Persada, 2007. h. 20-21. 
material Islam, dan jika belum ada aturan yang mengaturnya secara detail maka hakim berwenang melakukan pe-nggalian hukum dari khasanah fiqh Islam.

Dengan semikian, menurut hemat pe-nulis putusan Pengadilan Agama Pekanbaru sudah tepat, meskipun belum dilandasi oleh dasardasar dan pertimbangan putusan yang memadai. Apalagi dalam sistem peradilan, untuk menentukan kompetensi atau kewena-ngan absolut peradilan apabila terjadi seng-keta kewenangan mengadili, adalah dengan memandang kepada aturan hukum apa suatu perbuatan hukum dilakukan.

Hal tersebut, sama dengan ketentuan dalam Peraturan Perundang-Undangan yang ada di Negara Yordania, terdiri dari 12 Pasal yakni Pasal 154 sampai dengan Pasal 166 menjelaskan bahwa ketentuan hadhanah berlaku setelah terjadinya perceraian. Ada-pun syaratsyarat pemegang hak hadhanah, antara lain: dewasa, berakal, tidak meninggal-kan anak karena kesibukannya, mampu un-tuk mendidik dan menjaganya, tidak murtad, dan tidak menikah dengan lakilaki lain, jika salah satu syarat tersebut tidak terpenuhi maka gugurlah hak asuh anak tersebut. ${ }^{90}$ Begitu juga dengan ketentuan Peraturan Perundang-Undangan di Negara Syria men-jelaskan bahwa syaratsyarat pemegang hak hadhanah yaitu: dewasa, ber-akal, mampu mengasuh anak baik jasmani maupun rohani. Kemudian hak hadhanah seseorang dapat digugurkan apabila: pemegang hak hadhanah memiliki sifat tercela yang dapat mempenga-ruhi si anak, gila, dan murtad. Bahkan hak pengasuhan anak dapat digugurkan karena tidak mampu melakukan pengasuhan dengan alasan kesehatan. Apabila pemegang hak ha-dhanah mengaku sering meninggalkan rumah, dan tidak mempunyai kesempatan me-ngasuh anak, maka hak hadhanahnya di gugurkan, meskipun anak tersebut masih sangat kecil.

\section{Kesimpulan}

Pelaksanaan eksekusi hak asuh anak (hadhanah) dalam Putusan Perkara Nomor: 398/Pdt.G/2013/PA.Pbr di Pengadilan Ag-ama Pekanbaru, Antara Jonel Amran Bin Amran umur 43 tahun, sebagai Penggugat/ Pemohon Eksekusi dan lawannya adalah Ita Asnita Binti Abd Majid, umur 40 tahun, sebagai Tergugat/Termohon Eksekusi. Di-mulai dari tahapan pelaksanaan eksekusi di laksanakan hingga penyelesaian akhir sudah sesuai dengan pertimbangan dan aturan hukum yang berlaku di Indonesia. Namun ketika proses eksekusi itu dilakukan di kedia-man Tergugat/Termohon eksekusi berdasarkan isi Putusan Perkara Nomor: 398/Pdt. G/2013/PA.Pbr, keempat orang anak ini mengadakan perlawanan karena tidak berse-dia untuk di eksekusi, dan tetap memilih untuk ikut bersama ibunya (Tergugat/ Ter-mohon eksekusi), dan tidak bersedia ikut bersama ayahnya (Penggugat/Pemohon eksekusi). Sehingga penyelesaikan akhir per-kara dalam kasus tersebut ditunda sampai setelah anak tersebut mumayyiz dan diserah-kan pada anak untuk memilih ayah atau ibunya sebagai pemegang hak pemelihara-annya.

\section{Saran}

1. Kepada Pengadilan Agama Pekanbaru untuk terus memikirkan dan mencari langkah dan/atau jalan solusi terakhir bagaimana cara untuk supaya perkara ini bisa terselesaikan dengan apa yang diharapkan dan tidak memihak kepada pihak manapun, sehingga keputusan

${ }^{90}$ Ibid, h.139. 
yang di ambil benar-benar sesuai aturan yang berlaku, baik itu hukum positif, maupun hukum agama dan juga sesuai dengan rasio (akal).

2. Kepada Penggugat/Pemohon eksekusi untuk bersabar dalam menghadapi perkara ini, butuh waktu dan proses yang panjang untuk menyelesaikan ini semua, percayakan pada hukum yang ada. Karena secara aturan maupun pertimbangan hukum yang berlaku di Indonesia, khususnya di Pengadilan Agama Pekanbaru dan pelaksanaan-nya sudah sesuai aturan. Di dalam Pu-tusan Perkara Nomor: 398/ Pdt.G/ 2013/PA.Pbr juga sudah dilaksanakan, hanya dikarenakan faktor psikologis anak-anak yang masih mempunyai kedekatan jiwa dengan Tergugat/ Termohon (ibunya) yang sangat sulit di pisahkan. Berikan waktu untuk anakanak hingga bisa berpikir dan memilih mana yang diikuti. Untuk itu Penggugat/Termohon terus melaku-kan pendekatan kepada anak-anak, supaya ada timbul rasa kedekatan psikologis jiwa anak-anak dengan Penggugat/ Termohon.

Kepada Tergugat/Termohon untuk tidak mengasut kepada anak-anak un-tuk membenci Penggugat/ Pemohon (Ayahnya), walaupun sudah tidak bersama, dan bagaimanapun juga Penggugat/Pemohon merupakan ayah kandung dari anak-anak, Penggugat/ Pemohon juga mempunyai hak terhadap anak-anak untuk merawat, memelihara, menjaga dan membiayai anak-anak hingga mereka sampai pada usia dewasa. Diharapkan juga kepada Tergugat/ Termohon untuk komitmen dan konsekuensi terhadap 1 (satu) keyakinan, agama tidak boleh dimain-mainkan, seperti masuk pintu sana dan masuk pintu sini.

\section{Daftar Pustaka}

Abd Rahman Ghazaly, Fiqih Munaka-hat, (Jakarta: Prenada Media, 2013).

Abdul Aziz Dahlan, dkk, ed., Ensiklo-pedia Hukum Islam (Jakarta: Ichtiar Baru Van Hoeva, 1997).

Abdurrahman, Kompilasi Hukum Islam Di Indonesia, (Jakarta: Akademika Pressindo, 2007).

Abu Daud Sulaiman bin Al-Asy"eats, Sunan Abu Dand Jur. I, (Beirut: Daar Fikr, 2003).

Afifi Fauzi Abbas, Metodologi Penelitian (Jakarta: ADELINA Bersaudara, 2010), Cet.I

Al-Zarqa', Syarb al-Qawấ'id al-Fiqhiyah, Dar alGarb al-Islamy, 1983.

Syamsul Anwar, Prof.Dr, Hukum Per-janjian Syari'ah (Studi Tentang Teo-ri Akad dalam Fiqh Muamalat, ed-1, Jakarta, Raja Grafindo Persada, 2007.

Amir Syarifuddin, Hukum Perkawinan Islam di Indonesia: Antara Fiqh Mu-nakahat dan Undang-undang Perka-winan, (Jakarta: Kencana Pranada Media Group, 2009). Cet.III.

Andi Syamsu Alam dan M. Fauzan, Hukum Pengangkatan Anak Persfek-tif Islam, (Jakarta: Kencana, 2008), Cet.I

As-San'ani, Subulus Salam, (Surabaya: Al Ikhlas, 1995), Cet.III.

Bakhtiar Surat Tafsir Az-Zikra Bandu-ng, lentera 2005.

Bambang Sunggono, Metodologi Peneli-tian Hukum, (Jakarta: Raja Grafin-do Persada, 1998).

Bintania Aris. Hak Asuh (Hadhanah) Is-teri Murtad Menurut Hukum Po-sitif dan Hukum Islam (Analisis atas Putusan Pengadilan Agama Pangkalan Kerinci No: 13/Pdt.G/ 2009/PA. Pkc). (Jurnal. http:// media. neliti.com)

Harun Nasution, dkk, ed., Ensiklopedii Islam Indonesia (Jakarta: Djamba-tan, 1992).

Hasan Saleh, Kajian Fiqh Nabawi dan Fiqh Kontemporer, (Jakarta: PT Rajawali Pers, 2008).

Huzaemah Tahido Yanggo, Fikih Pe-rempuan Kontemporer. (Jakarta: Ghalia Indonesia, 2010).

Ibrahim Muhammad Al-Jamal, Fiqih Muslimab: Ibadat Mu'amalat, (Ja-karta: Pustaka Amani, 1999), Cet. III. 
Intruksi presiden Nomor 1 Tahun 1991 tentang penyebarluasan kompi-lasi hukum islam.

Kamal Muchtar, Asas Hukum Islam Ten-tang Perkawinan, Jakarta: Bulan Bintang, 1974), Cet.I.

Muhammad Uwaidah dan Syaikh Ka-mil Muhammad, Fiqh Wanita, Ja-karta: Pustaka Al- Kautsar, 2004).

Peunoh Daly, Hukum Perkawinan Islam: Suatu Studi Dalam Kalangan Ab-lus-sunnah dan Negara-negara Is-lam, (Jakarta: Bulan Bintang, 20-05).

Rianto Adi, Metodologi Penelitian Sosial dan Hukum (Jakarta: Granit,2010), Cet.III.

Satria Effendi M. Zein, Problematika Hukum Keluarga Islam Kontempo-rer. Kencana, Jakarta, 2004.

Sayyid Sabiq, Fiqih Sunnah Sayyid Sabiq Jilid 2, (Jakarta: Al-I" tishom, 20-08).

Syaikh Hasan Ayyub, Fikih Keluarga, (Jakarta: Pustaka Al-Kautsar, 20-06), Cet.V.

Syeikh Al-Syihab Al-Din Al-Qalyabi Wa Al„Umairah, Al-Mahalli Juz IV, (Kairo: Dar Wahya Al-Kutub, 1971).

Tatang M. Amirin, Menyusun Rencana Peneli-tian (Jakarta: PT Raja Grafindo Per-sada, 1995).

Undang-Undang Nomor 23 Tahun 2002 Tentang Perlindungan Anak

Undang-Undang Nomor 1 Tahun 1974 Tentang Perkawinan.

Wahbah Al-Zuhaili, Al-Figh Al-Islami wa Adillatuh (Damaskus: Daar Al-Fikr, 1984).

Yahya Harahap, Hukum Perkawinan Nasional, (Medan: CV Zahir Trading CO, 1975).

Zahri Hamid, Pokok-Pokok Hukum per-kawinan Islam dan Undang-Undang Perkawinan di Indonesia, (Yogya-karta: Bina Cipta, 1978), Cet.I. 